\title{
Factors Affecting the Presence and the Diversity of Bryophytes in the Petrifying Sources Habitat (7220) in Wallonia and the Brussels-Capital Region, Belgium
}

\author{
J.-M. Couvreur, ${ }^{1}$ G. San Martin, ${ }^{2}$ and A. Sotiaux ${ }^{3}$ \\ ${ }^{1}$ Département de l'Etude du Milieu Naturel et Agricole, Service Public de Wallonie, Gembloux, Belgium \\ ${ }^{2}$ Centre Wallon de Recherches Agronomiques, Gembloux, Belgium \\ ${ }^{3}$ National Botanic Garden, Meise, Belgium
}

Correspondence should be addressed to J.-M. Couvreur; jeanmarc.couvreur@spw.wallonie.be

Received 9 March 2016; Revised 10 July 2016; Accepted 31 July 2016

Academic Editor: Karl H. Hasenstein

Copyright (C) 2016 J.-M. Couvreur et al. This is an open access article distributed under the Creative Commons Attribution License, which permits unrestricted use, distribution, and reproduction in any medium, provided the original work is properly cited.

\begin{abstract}
Bryological composition, water chemistry, and environmental factors were characterized on 67 Belgian travertines. We explore the relationship between these environmental factors and the community composition, species richness, or presence of individual species using Redundancy Analysis with Hellinger's transformation (tb-RDA) or Generalized Linear Models (GLMs). The best variables explaining the community composition are slope, $\mathrm{NO}_{3}, \mathrm{NH}_{4}$, and $\mathrm{PO}_{4}$. The species richness is negatively related to canopy cover and $\mathrm{PO}_{4}$. Palustriella commutata tends to be more frequent when the slope is steeper and to a lesser degree when the canopy cover is lower. Eucladium verticillatum tends to be slightly more frequent when canopy cover and $\mathrm{NH}_{4}$ concentrations are lower. Cratoneuron filicinum is more frequent at higher $\mathrm{Mg}$ concentrations and Pellia endiviifolia is more frequent at lower $\mathrm{PO}_{4}$ concentrations and higher $\mathrm{NO}_{3}$ concentrations. Brachythecium rivulare showed wide ecological amplitude and almost none of the tested environmental factors seem to be related to its presence. The study identifies eutrophication as the main factor responsible for habitat deterioration. Practical indications on the best ways to maintain or to enhance the quality of these petrifying sources are given.
\end{abstract}

\section{Introduction}

"Travertine" or "tufa" deposits include a wide variety of calcareous substrates that are characterized not only by their mineral composition but also by their morphology and processes by which they form. There are many interpretations and definitions of the terms tufa and travertine (Symoens et al. [1], Couderc [2], Pentecost [3], De Zuttere [4], Viles and Goudie [5], Ford and Pedley [6], Janssen and Swennen [7], Merz-Preiß and Riding [8], Boch et al. [9], Franco et al. [10], and Brusa and Cerabolini [11]). The term "travertine" is often used to describe calcareous substrates formed during warm periods or in warm environment including thermal springs and that contain no or very few organic material other than bacteria $[6,7]$. In contrast, the term "tufa" is generally used to describe substrates formed in colder environments and containing organic material [6].
It is possible for both warm and cold travertine formation to occur simultaneously, as evidenced by several Belgian locations including the Hoyoux river near Huy and on the "Ry de Matignolles" stream near Treignes [10].

Although the European definition of the habitat [12] uses the term "tufa" we will use the term "travertine" in accordance with Pentecost [13] as the term "tufa" relates more to a soft and poorly consolidated variety of travertine.

In the framework of the mapping of Natura 2000 sites in Wallonia, south Belgium, we had the opportunity to undertake research on the ecology of the priority habitat "Petrifying springs with tufa formation (Cratoneurion) 7220." The code 7220 is specific to this priority habitat in the Interpretation Manual of European Union Habitats [12]. This priority habitat generally consists of small point or linear formations dominated by bryophytes (Cratoneurion commutati Koch, 1928, communities). The manual [12] provides a list 
of characteristic species for each habitat type; however, these lists have to be adapted at the national or regional scale. In Wallonia, two bryophyte species are considered strictly linked to the 7220 habitat, Palustriella commutata (Hedw.) Ochyra and Eucladium verticillatum (With.) Bruch \& Schimp. Palustriella commutata (Hedw.) Ochyra has been split into two species by some authors [14]; however, in this study we consider both as Palustriella commutata.

The following are considered to be good companion species and are also included in the Walloon definition when assessing the habitat conservation status [15]: Aneura pinguis (L.) Dumort., Conocephalum conicum (L.) Dumort., Jungermannia atrovirens Dumort., Leiocolea badensis (Gottsche.) Jörg., Pellia endiviifolia (Dicks.) Dumort., Preissia quadrata (Scop.) Nees, Brachythecium rivulare Schimp., Bryum pseudotriquetrum (Hedw.) P. Gaertn. et al., Ctenidium molluscum (Hedw.) Mitt., Cratoneuron filicinum (Hedw.) Spruce, Dichodontium pellucidum (Hedw.) Schimp., Didymodon tophaceus (Brid.) Lisa, Fissidens adianthoides Hedw., Fissidens crassipes Wilson ex Bruch \& Schimp., Gymnostomum calcareum Nees \& Hornsch., Hymenostylium recurvirostrum (Hedw.) Dixon, Philonotis calcarea (Bruch \& Schimp.) Schimp., Plagiomnium ellipticum (Brid.) T. J. Kop., Plagiomnium rostratum (Schrad.) T. J. Kop., Plagiomnium undulatum (Hedw.) T. J. Kop., and Seligeria trifaria (Brid.) Lindb. Cratoneuron filicinum is considered a good characteristic species in other regions and countries, for example, Flanders and the Brussels-Capital Region [16], Great Britain [17], and the Netherlands [18]. However, it was not included in the small group of characteristic species as it is far more widespread in Wallonia than the two other species [19], occurring in a variety of different habitats, including man-made calcareous forest tracks. Nonetheless Cratoneuron filicinum is considered to be a good companion species for the 7220 habitat in Wallonia [15].

In Wallonia [15], the 7220 habitat is mainly associated with calcareous springs and small streams (width $<5 \mathrm{~m}$ ) where incrustation processes occur. An atypical form of the habitat is represented in Wallonia by the "travertins" formed in the Hoyoux river consisting of calcareous deposits across the river (barrages) or its tributaries whose width can reach 10 to $20 \mathrm{~m}$. The $7220^{*}$ habitat in Wallonia [15] is characterized by Ca-rich waters (110-120 mg. $\mathrm{L}^{-1}$ ) and high $\mathrm{pH}$ values (7.5-8.5) but depending on the subregion the substrate can be mostly sandy with calcareous incrustations (sandy-loam region) or more compact calcareous rocks (Condroz, FamenneCalestienne, Lorraine) where they are locally called "crons" or "crânières" [1, 20-24].

From a phytosociological point of view, most of the springs and small streams of Wallonia and BrusselsCapital Region can be attributed to the Montio-fontanaeCardaminetea-amarae Braun-Blanquet et Tüxen, 1943, Class $[16,25,26]$. Following Bardat and Hauguel [26] and depending on the local situations the bryophytes communities can then be linked to the Caricion remotae Kästner, 1941, Alliance (intraforest communities of oligo-mesotrophic soils), to the Pellion endiviifoliae Bardat, 1998, prov.nov. Alliance (neutro-alkaline small streams), or to the Riccardio-Eucladion verticillati Bardat, 1998, prov.nov. Alliance (Ca-rich and thermophilous soils). Following Zechmeister and Mucina [16, 25], Belgian communities can be linked to the Cratoneurion commutati Koch, 1928, Alliance (sunny springs with highly oxygen-saturated waters), to the Adiantion Br.-Bl. ex Horvatic, 1934, em. Hoc. Loco Alliance (waters with high $\mathrm{Ca}$ contents and high summer temperatures), or to the Caricion remotae Kästner, 1941, Alliance (intraforest communities of oligotrophic waters).

The bryological aspects of travertines and their phytosociological composition are well documented in Belgium [1, $4,16,21,22,27,28]$, the Netherlands [18, 27], Italy [29], France [2, 26, 30], and in a wider European context [25]. However, relatively few studies have been undertaken on datasets that consider the driving environmental variables that could influence the distribution of particular species and the species richness of these habitats [11, 31-35].

The aims of this research were (1) to learn more about the variables, both physical and chemical, that can affect bryophyte diversity in the surveyed sites; (2) to evidence the most significant variables that can affect the presence or absence of the more characteristic species; (3) to give practical indications on the best ways to maintain or to enhance the quality of this habitat both in Wallonia and the BrusselsCapital Region.

\section{Materials and Methods}

2.1. Data Collection. Most of the surveyed sites lie in Wallonia, south Belgium (Figure 1), where 62 sites were identified, representing the widest variety of conditions within the 7220 habitat. Wallonia is not a homogeneous region as it consists of 5 subregions characterized by geomorphological specificities (from north to south: sandy Loess Plateau, psammitic Condroz, calcareous Famenne-Calestienne, acidic siliceous Ardennes, and calcareous Lorraine). Petrifying sources are mainly small habitats; however, they are relatively widespread in all these subregions except the Ardennes where it is virtually absent due to the acidic siliceous substrate and in the sandy Loess Plateau where there were also fewer sites. To increase the coverage, we added 5 sites within the Loess region by including some of the Brussels-Capital Region localities.

On each Walloon site a comprehensive sampling regime (random selection of all known locations) was undertaken during autumn, 2012; the bryophytes were identified in the laboratory (A. Sotiaux). Sampling of the 5 locations in the Brussels-Capital Region was undertaken during autumn, 2014, with bryophytes identified in the laboratory (J.-M. Couvreur). We collected bryophytes that are directly associated with areas of travertine and to avoid "noise" in the final dataset we also dropped before analysis species that were not directly related to the 7220 habitats. Moreover, as it is sometimes difficult to assess the rate of abundance or cover by these bryophytes especially in this kind of rather heterogeneous habitat, we decided to only mention the presence/absence of these species. 

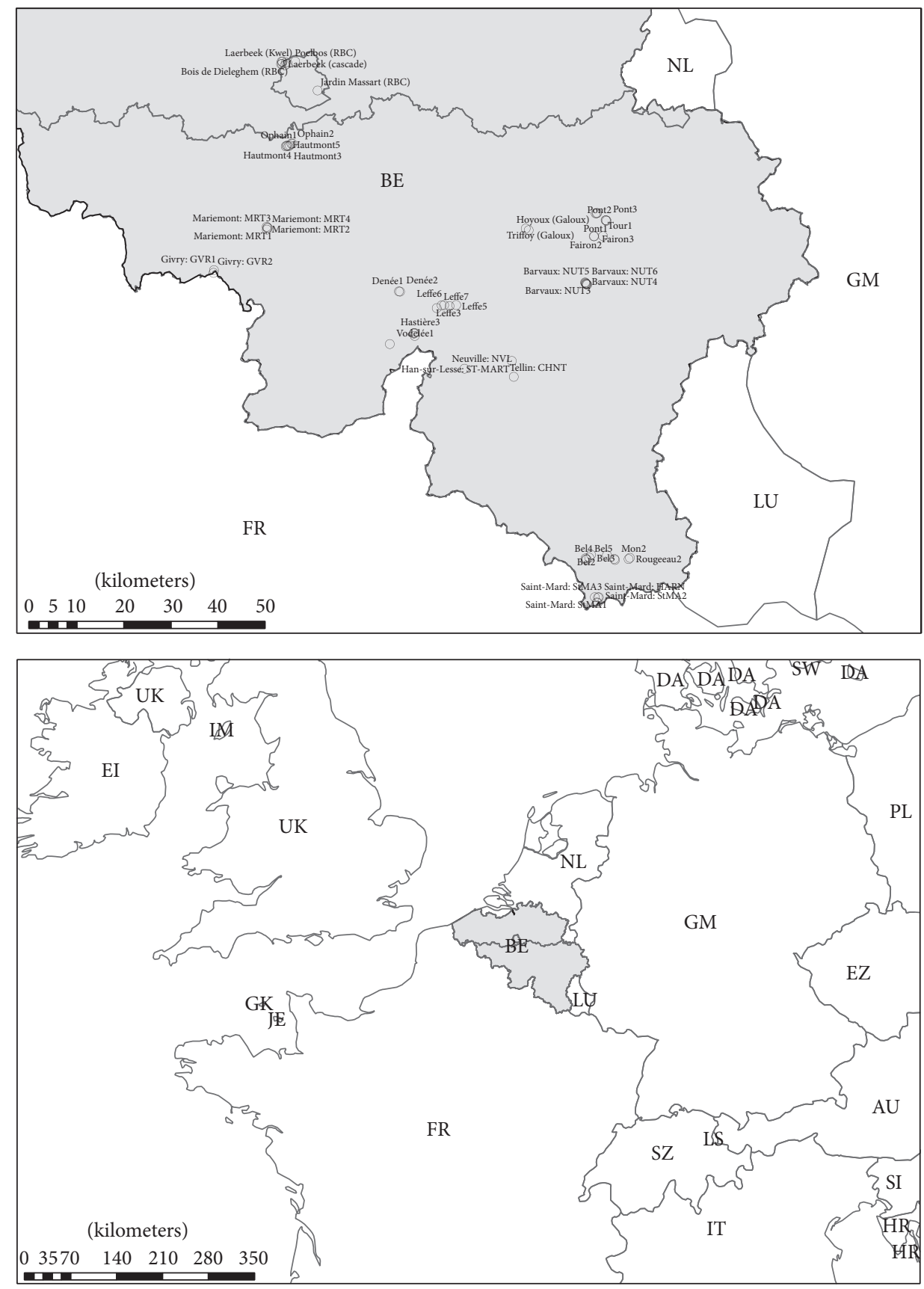

FIGURE 1: Location of most of the 67 surveyed petrifying sources (some locations are close to each other and cannot be represented here). Belgium (BE) is displayed in grey and the lines inside delimit the 3 administrative regions (Flemish at the north, Brussels-Capital Region just above the Flemish-Walloon border, and Walloon beneath).

Distance from the spring was not measured but the physical and physicochemical variables, including slope, orientation, canopy cover, and water chemistry, were measured at the location of each bryophyte sample. The physical variables were measured first, including slope, orientation, and canopy cover. Slope was estimated visually and classified into three groups: low $(0.5-7.5 \%)$, moderate $(7.5-20 \%)$, and steep $(>20 \%)$. The orientation was measured using a compass (the four cardinal points plus the four intermediate ones). The percentage of canopy cover (\%) was measured visually. Water chemistry, the second group of variables, was measured at each site on the same day that the bryophytes were collected. The water sample was obtained by collecting one litre of water flushing through the site in a glass bottle. The glass bottles were kept cool by storing them in cool boxes with freeze packs, until they were transferred to a laboratory fridge. The $\mathrm{pH}$ was measured in the lab using a WTW197i multimeter; other physicochemical variables were measured using a DR3900 Hach Lange photometer: conductivity $(\mu \mathrm{S} / \mathrm{cm})$, nitrates 
$\left(\mathrm{N}-\mathrm{NO}_{3} \mathrm{mg} \cdot \mathrm{L}^{-1}\right)$, ammonium $\left(\mathrm{N}-\mathrm{NH}_{4} \mathrm{mg} \cdot \mathrm{L}^{-1}\right)$, soluble orthophosphates $\left(\mathrm{P}-\mathrm{PO}_{4} \mathrm{mg} \cdot \mathrm{L}^{-1}\right)$, nitrites $\left(\mathrm{N}-\mathrm{NO}_{2} \mathrm{mg} \cdot \mathrm{L}^{-1}\right)$, water hardness ( $\mathrm{dH}$ degrees), calcium $\left(\mathrm{Ca} \mathrm{mg} \cdot \mathrm{L}^{-1}\right)$, and magnesium ( $\mathrm{Mg} \mathrm{mg} \cdot \mathrm{L}^{-1}$ ). Information including locality, date, location ( $X$ and $Y$ Lambert 1972 coordinates), and biogeographical region (Atlantic or Continental mentioned in the variable "Zone") was also recorded at each site.

2.2. Analysis. All of the analyses were performed with R 3.2.1 [36]. We removed one dataset from the analysis (Leffe6) for which $\mathrm{NO}_{2}$ and $\mathrm{NO}_{3}$ values were completely unrealistic, even in highly eutrophicated waters. Four missing values in three different explanatory variables (two for $\mathrm{PO}_{4}$, one for $\mathrm{Ca}$, and one for $\mathrm{Mg}$ ) were modelled because the AIC approaches we intended to use are incompatible with missing values. We built three Gaussian linear models, one for each variable with missing values, with the other environmental variables as predictors; however, the species data were not used. The missing data were replaced by the predicted value from these models.

The relationship between bryophyte community composition (presence/absence matrix) and the environmental factors was studied with a Hellinger transformation based Redundancy Analysis (tb-RDA [37]) performed with vegan 2.3-1 package [38]. We checked that the environmental variables were able to explain at least a part of the variance of the species matrix with a global permutation test (ANOVA function in vegan, 999 permutations). We then applied a simple forward selection procedure based on sequential permutation tests (ordistep function from vegan) to identify the environmental variables that are most related to species composition.

The relationship between species richness (total number of species) and the environmental predictors was analysed with a Poisson Generalized Linear Model (GLM). Binomial GLMs were used to characterize the presence/absence of a few individual species relative to the environmental predictors. These binomial GLMs were built only for species that were present on 20 of the 67 sites (Palustriella commutata, Eucladium verticillatum, Cratoneuron filicinum, Pellia endiviifolia, and Brachythecium rivulare).

For all GLMs, model conditions (linearity, distribution, and outliers) were checked with residuals plots and overdispersion was checked for the Poisson GLM. Multicollinearity between the explanatory variables was checked graphically and by computing Variance Inflation Factors (VIFs). If necessary, some of the explanatory variables were dropped in order to keep the VIFs $<5$. We centred the $\mathrm{pH}$ explanatory variable on its mean value to avoid predictions at the intercept for $\mathrm{pH}$ $=0$, that is, completely outside the range of observed values. The absence of spatial correlation of the models residuals was checked with splines correlograms.

In order to determine the most important explanatory variables for these GLMs, we applied an AICc based model selection procedure as described by Burnham and Anderson [39] and shortly summarized hereafter. GLMs with all possible combinations of explanatory variables were computed. Their AICc and AICc model weights were calculated. The
AICc model weight quantify the model selection uncertainty and can be interpreted as the probability for a given model to be selected as the best model (the one with lowest AICc) in a set of models if we could resample the data. Then for each explanatory variable we computed a variable weight as the sum of the AICc weights of the models in which this explanatory variable is present. This variable weight is a measure of the relative importance of the explanatory variables. We interpreted only the explanatory variables with an AICc weight $>0.6$. The shrinkage model averaged coefficients were then computed along with their unconditional standard errors. These model averaged coefficients are the mean of the coefficient of all models weighted by the model quality (AICc model weights).

For the biological interpretation of the GLMs outputs we plotted graphs, based on model averaged coefficients, for the most important explanatory variables in the range of their observed values. The explanatory variables that are not drawn on the graphs are fixed to their mean value.

\section{Results}

3.1. Dataset. The results of the field campaign are presented in Table 1(a) (physicochemical variables) and Table 1(b) (species) as two matrices with the 67 sites as lines and the species or environmental factors as columns. The "Leffe6" site is mentioned; however, it was removed due to "out of range" values of $\mathrm{NO}_{2}$ and $\mathrm{NO}_{3}$. The 4 missing values were replaced by their predicted ones in the final matrix by using an explanatory GLM model based on the other variables. These values are, respectively, 0.055 and $0.058 \mathrm{mg} \cdot \mathrm{L}^{-1} \mathrm{PO}_{4}$ for sites MRT1 and MRT2, respectively, $51.06 \mathrm{mg} \cdot \mathrm{L}^{-1}$ Ca for site GVR2 and $25.52 \mathrm{mg} \cdot \mathrm{L}^{-1} \mathrm{Mg}$ for site MRT4.

Three pairs of explanatory variables were highly correlated: conductivity-Ca (0.8), conductivity-water hardness (0.77), and water hardness-Ca (0.85). We decided to drop the variables conductivity and water hardness which were highly correlated to the Ca concentration and to keep the last one for the next step analysis.

3.2. Key Variables of Species and Sites Assemblages. The tbRDA analysis (Table 2) using the list of previously retained quantitative and qualitative variables $\left(\mathrm{pH}, \mathrm{NO}_{3}, \mathrm{NH}_{4}, \mathrm{PO}_{4}\right.$, $\mathrm{NO}_{2}, \mathrm{Ca}, \mathrm{Mg}$, slope converted into numerical values from 1 to 3 , canopy cover and orientation). The first unconstrained axis (PCA1) explains a rather high amount of variation, almost comparable to the first constrained axis, RDA1. This suggests that there is another environmental variable, not measured during this study, which could influence the species composition of the communities (see Section 4). Nevertheless the variables explain $36.5 \%$ of the variation and a Monte Carlo permutation test executed on this RDA delivers a highly significant value for the model $(P<0.001)$ that confirms the global model is relevant.

Inside the constrained variance the first axis explained $44.9 \%$ (= eigenvalue RDA1 $=0.4282 / 0.9524)$ of this constrained variance and the second axis $18.1 \%$ (= eigenvalue $\mathrm{RDA} 2=0.1721 / 0.9524)$. The use of the same dataset without 


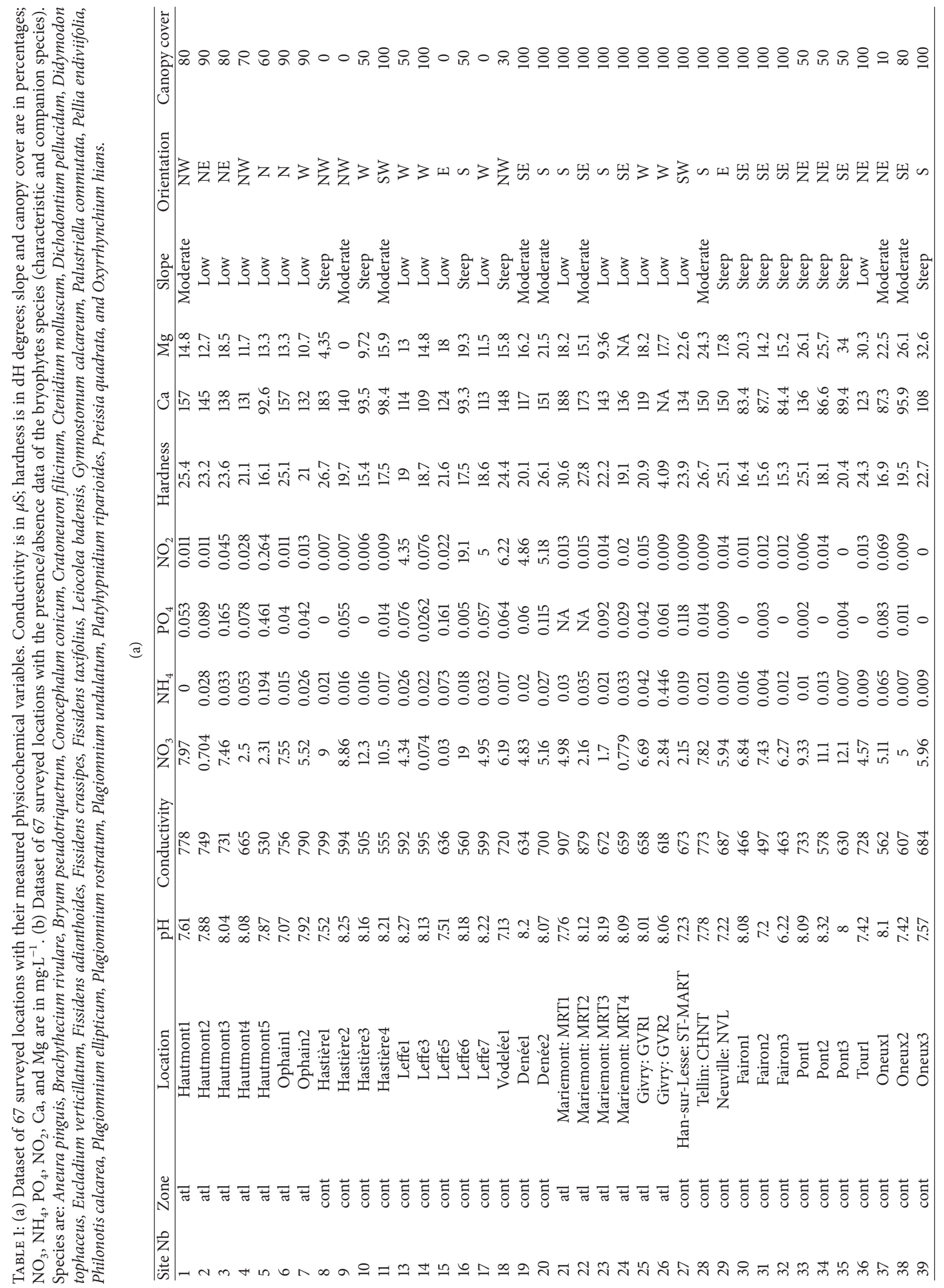




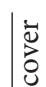

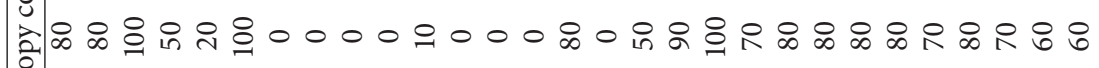
Uี

등

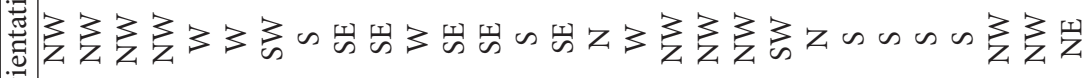
○一

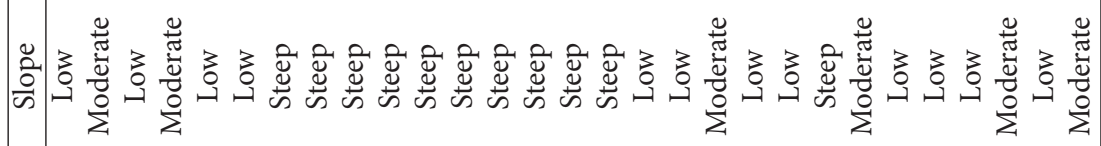

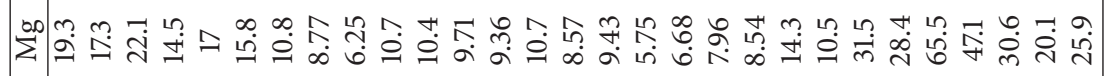

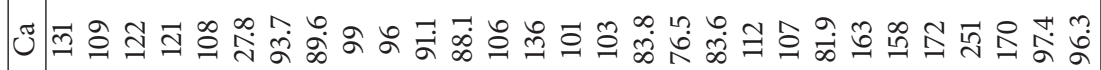
\&

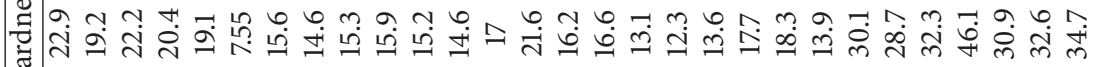
ב⿱乛龰

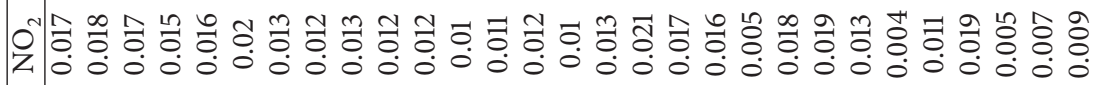

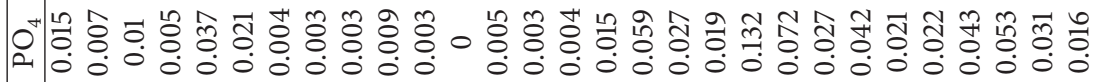

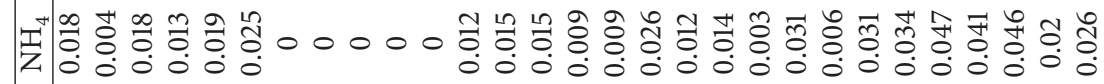

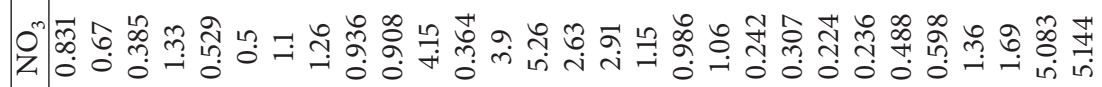
.

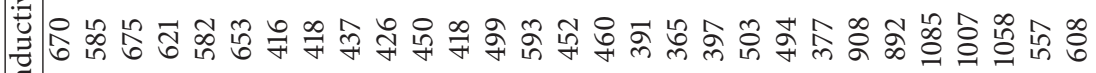

ชี

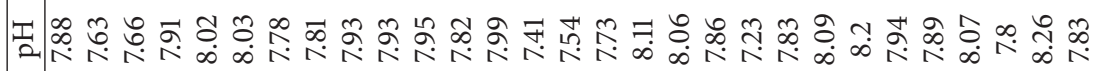

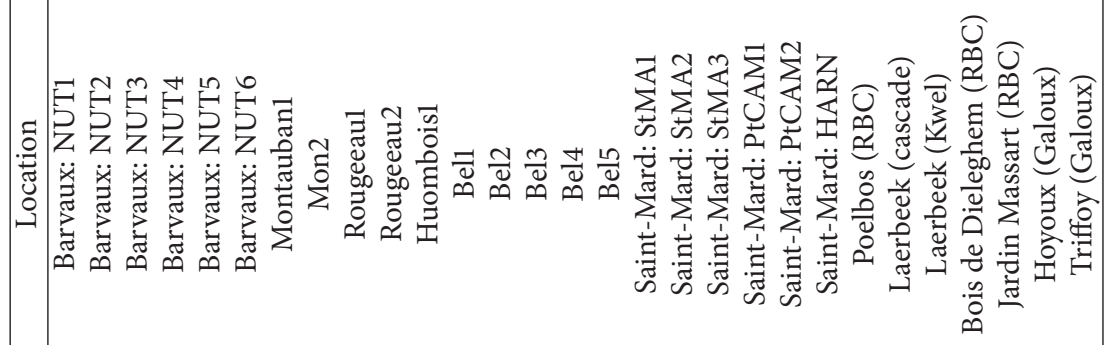

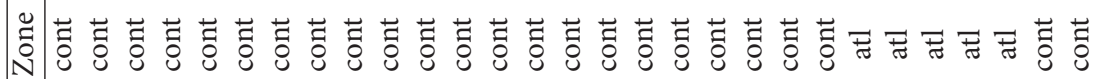
Z

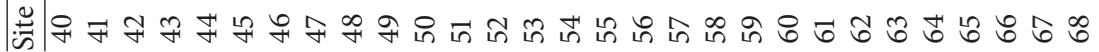

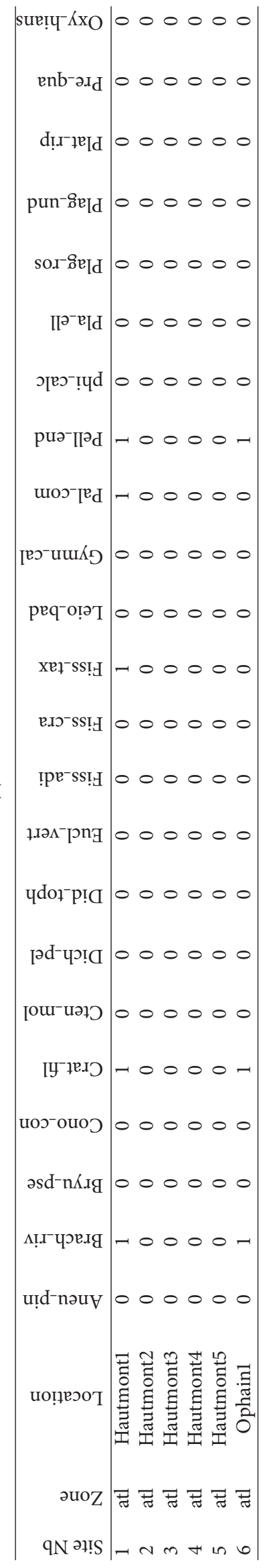




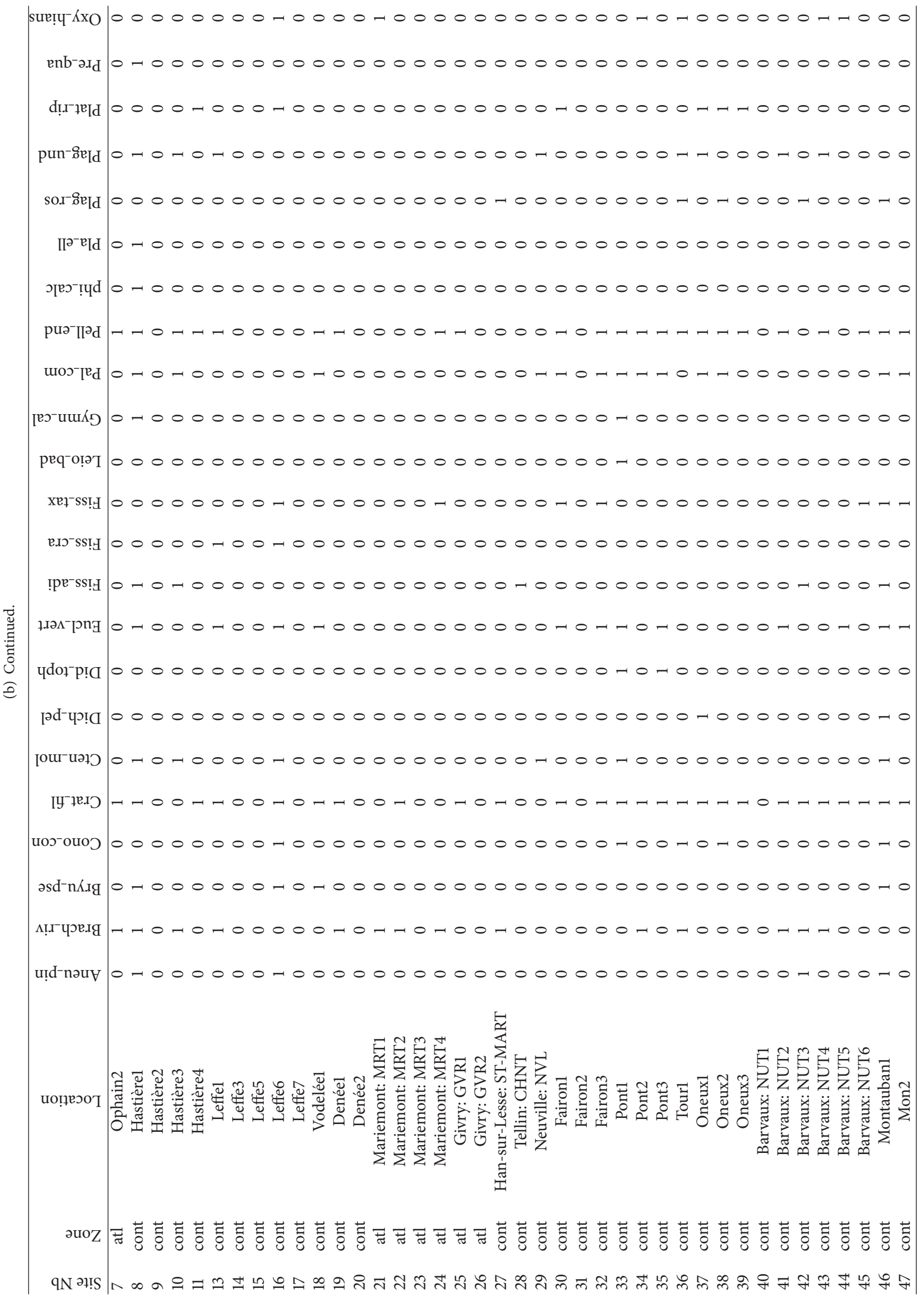




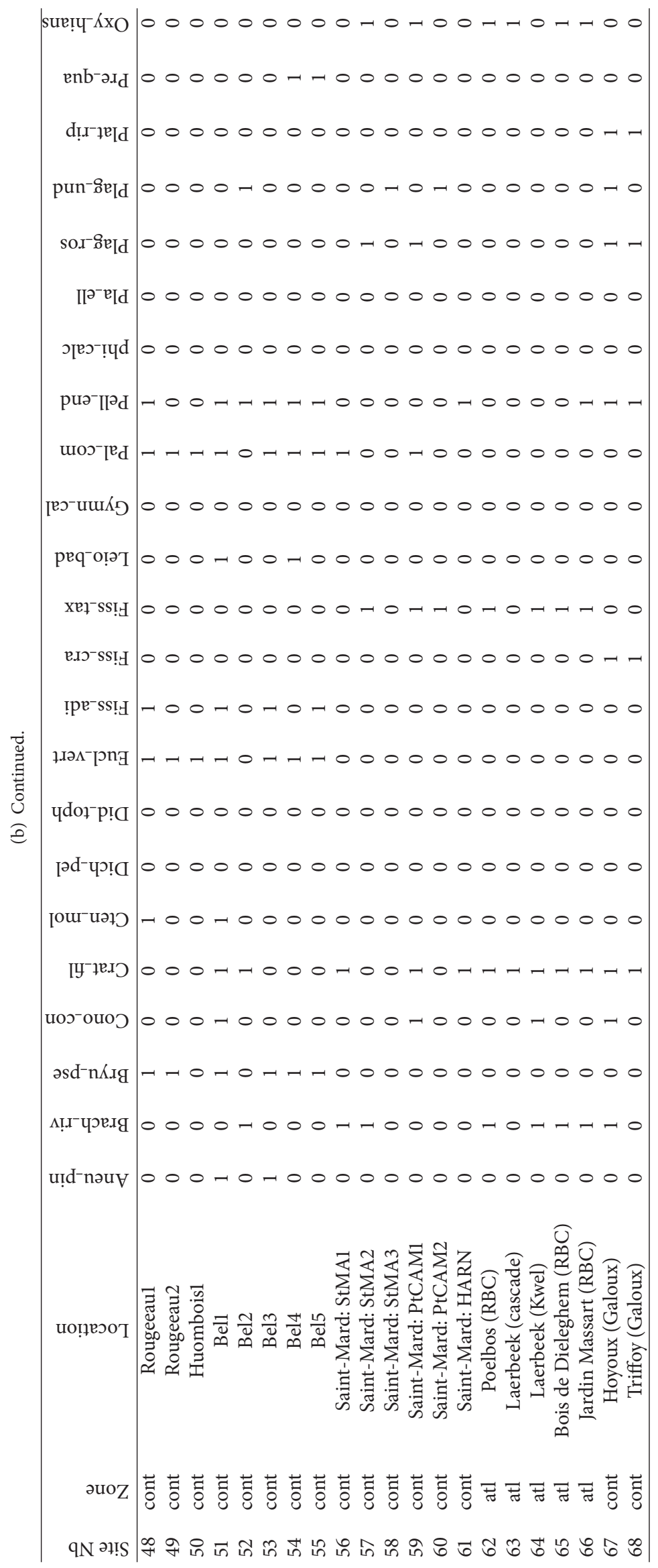


TABLE 2: Results of the tb-RDA analysis.

\begin{tabular}{lccc}
\hline Dataset & $\begin{array}{c}\text { Percentage of variation } \\
\text { explained by the variables } \\
\text { (constrained variation) }\end{array}$ & $\begin{array}{c}\text { Percentage explained by } \\
\text { first axis inside constrained } \\
\text { variation }\end{array}$ & $\begin{array}{c}\text { Percentage explained by } \\
\text { second axis inside } \\
\text { constrained variation }\end{array}$ \\
\hline With outliers and orientation variable & 36.5 & 44.9 & 18.1 \\
Without outliers and with orientation variable & 38.3 & 42.8 & 15.4 \\
With outliers and without orientation variable & 28.3 & 55.9 & 17.7 \\
\hline
\end{tabular}

the two outliers yields approximately the same results $(38.3 \%$ of constrained variation, $42.7 \%$ for the first axis, and $15.4 \%$ for the second axis). As the parameter orientation is not retained by the forward selection model and because it produces a poorly readable figure, we also tested the same model without the orientation variable (Figure 2). The results are the following: $28.3 \%$ of constrained variation, $55.9 \%$ for the first axis, and $17.7 \%$ for the second axis.

The RDA analysis is potted both with and without the orientation variable (Figure 2). The scaling 2 option [37] allows the following comments and shows that slope, $\mathrm{NO}_{3}$, $\mathrm{NH}_{4}, \mathrm{PO}_{4}$, and canopy cover play an important role in the dispersion of the sites along the first axis.

The two variables $\mathrm{NH}_{4}$ and $\mathrm{PO}_{4}$ are very closely correlated, suggesting that they can act in a similar way on the species assemblages and between factors themselves; however, $\mathrm{NO}_{3}$ is negatively correlated with both $\mathrm{NH}_{4}$ and $\mathrm{PO}_{4}$. The two characteristic species Eucladium verticillatum and Palustriella commutata are close together suggesting they appear both on sites with higher slope and lower cover of canopy and lower $\mathrm{NH}_{4}$ and $\mathrm{PO}_{4}$ concentrations. Pellia endiviifolia shows a positive relationship with $\mathrm{NO}_{3}$ whereas Brachythecium rivulare and Oxyrrhynchium hians (Hedw.) Loeske are weakly correlated with $\mathrm{PO}_{4}, \mathrm{NH}_{4}$, and high $\mathrm{pH}$ values. Bryum pseudotriquetrum is negatively correlated with canopy cover. Most other species are clustered together away from these extremes. They show mostly shorter projections, indicating that they are either present in most of the sites or related to intermediate ecological conditions; however, they could also be related to some variables on third or higher axis which is not displayed.

The result of the forward model selection of the RDA retained a model with (sorted by decreasing importance) slope, $\mathrm{Mg}$, $\mathrm{Ca}$, and canopy cover $($ spe $\sim$ slope $+\mathrm{Mg}+\mathrm{Ca}+$ cover). The same analysis without the outliers ("Haumont5" and "Givry2") generates a slightly different model with slope, canopy cover, $\mathrm{Mg}$, and $\mathrm{Ca}$ as the most significant factors (spe $\sim$ slope + cover $+\mathrm{Mg}+\mathrm{Ca})$.

3.3. Species Richness. The results show (Table 3) that only two explanatory variables (canopy cover and $\mathrm{PO}_{4}$ ) are strongly supported by the data (variable weight $=0.992$ and 0.960 , resp.) while two other ones are moderately supported by the data $\left(\mathrm{NH}_{4}\right.$ and $\left.\mathrm{Mg}\right)$ with a weight of, respectively, 0.709 and 0.650 . All but the $\mathrm{Mg}$ variables are negatively correlated with species richness.

To check the potential influence of outliers we performed the same analysis after excluding Haumont5 and Givry2 sites which have very high $\mathrm{PO}_{4}$ and $\mathrm{NH}_{4}$ values. The model selection results are comparable to the first analysis including outliers; AIC retains only canopy cover and $\mathrm{PO}_{4}$ as the main explanatory variables (Table 3 ) (columns on the right for each parameter).

Figures 3 and 4 show the results of two predicted scenarios based on the complete model (2 outliers included) with the mean values of other variables. Figure 3 represents the relation between the $\mathrm{PO}_{4}$ concentration and the species richness and Figure 4 represents the relation between the canopy cover and the species richness. It can be seen that for the canopy cover the expected number of species rises by 2 or 3 species (going approximately from 2 to 4 or even 5) when the cover falls from 100 to $0 \%$. In the case of the $\mathrm{PO}_{4}$ concentration the expected number of species falls to zero when the $\mathrm{PO}_{4}$ concentration rises from 0 to $0.5 \mathrm{mg} \cdot \mathrm{L}^{-1}$ or more.

\subsection{Presence/Absence of Characteristic and Companion} Species. For each species we began by excluding the variables that were highly correlated using the VIF (Variance Inflation Factor) values. The only variable to exclude from the five species was orientation and thus the binomial GLM analysis included the following explanatory variables: zone, $\mathrm{NO}_{2}$, $\mathrm{Mg}$, pH_mean, $\mathrm{Ca}, \mathrm{NH}_{4}, \mathrm{NO}_{3}$, canopy cover, slope, and $\mathrm{PO}_{4}$.

3.4.1. Palustriella commutata. The most important variables delivered by the AIC procedure are "steep slope" and "moderate slope" and to a lesser extend "canopy cover" (Table 4). The frequency of Palustriella commutata tends to increase when the slope is steeper and decreases when canopy cover is higher (Figure 5).

3.4.2. Eucladium verticillatum. The most important variables delivered by the AIC procedure are canopy cover and $\mathrm{NH}_{4}$, both are negatively correlated with the probability of the presence of the species (Table 5). The frequency of Eucladium verticillatum tends to decrease when the canopy cover increases and for higher concentrations of $\mathrm{NH}_{4}$, however the size of the effect is relatively limited as shown on Figure 6.

3.4.3. Cratoneuron filicinum. The only important variable delivered by the AIC procedure is the $\mathrm{Mg}$ concentration (positive relationship) and to a lesser degree $\mathrm{NH}_{4}$ (negative relationship) (Table 6, Figure 7). The results remain similar after excluding the "Laarbeek (Kwel)" site whose outlying value $\left(65.5 \mathrm{mg} \cdot \mathrm{L}^{-1}\right)$ could have unduly influenced the correlation. 


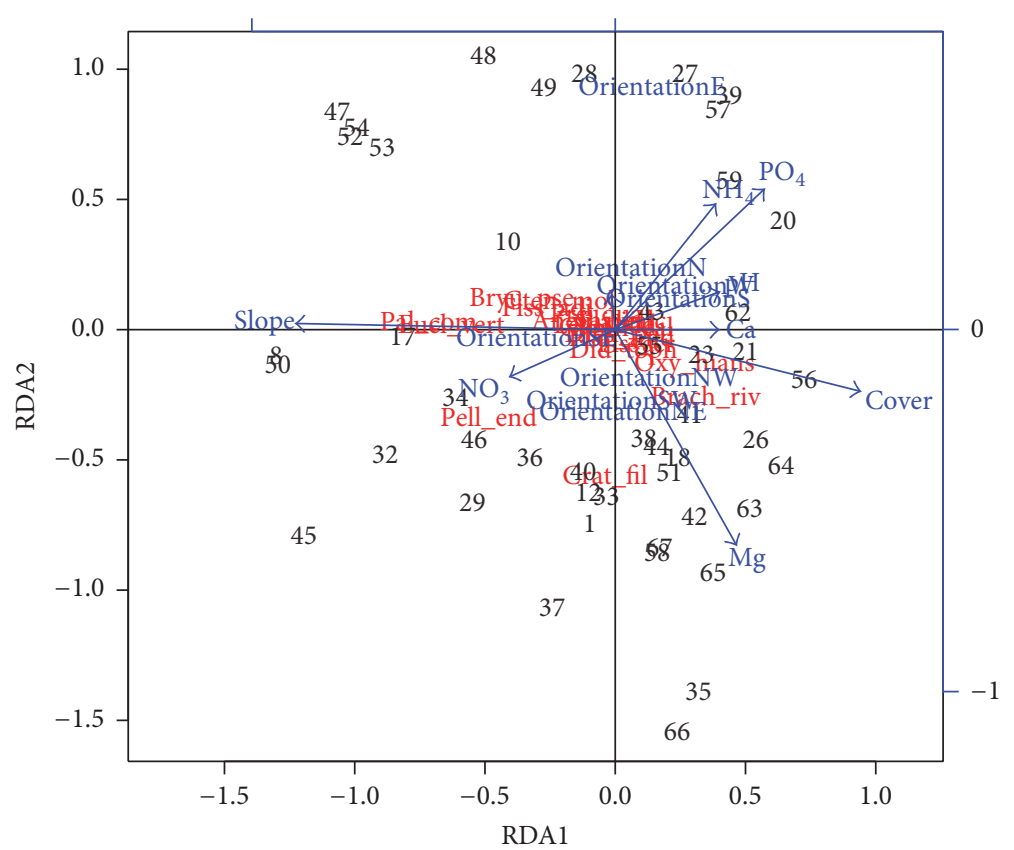

(a)

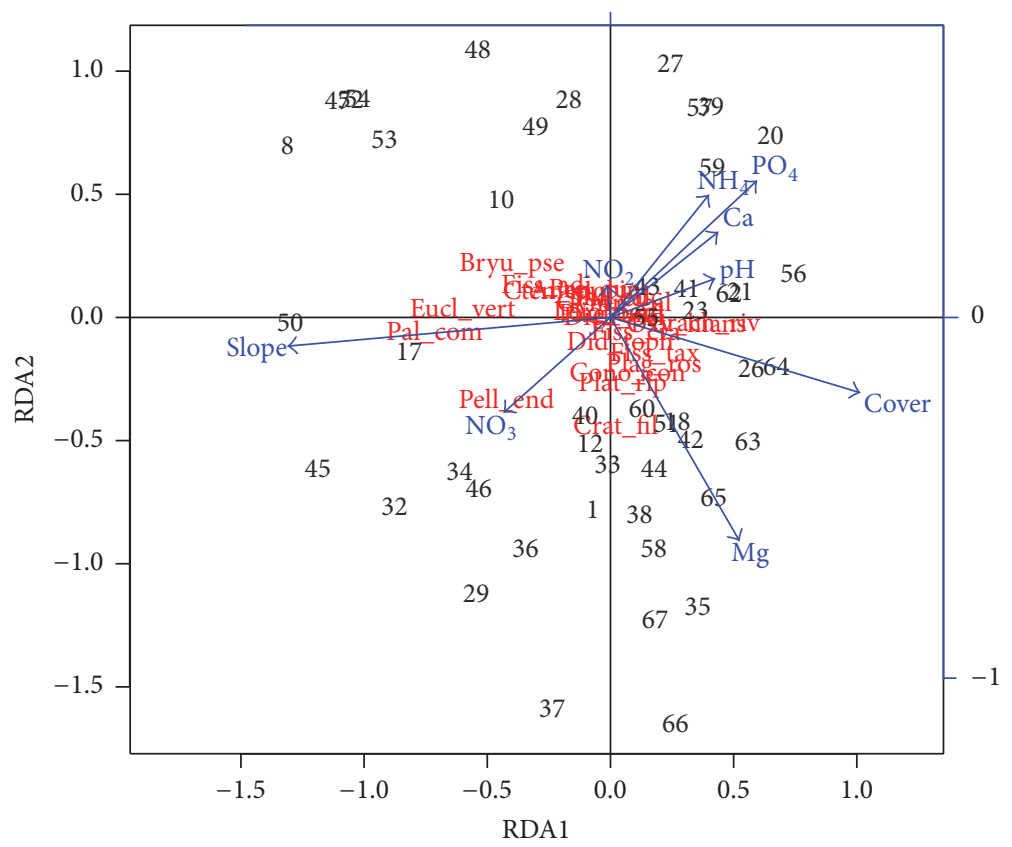

(b)

Figure 2: Plot of the tb-RDA analysis with (a) and without (b) orientation variable.

3.4.4. Pellia endiviifolia. The most important variables delivered by the AIC procedure are $\mathrm{PO}_{4}$ (negative relationship) and $\mathrm{NO}_{3}$ (positive relationship) (Table 7; Figure 8).

3.4.5. Brachythecium rivulare. The only important variable delivered by the AIC procedure is the $\mathrm{Ca}$ concentration (positive relationship) (Table 8). However Figure 9 shows that this correlation is weak and is based almost entirely on the outlying value $\left(251 \mathrm{mg} \cdot \mathrm{L}^{-1}\right)$ of the "Bois de Dieleghem" site.
It would thus be sensible to not pay too much attention to this correlation.

\section{Discussion}

This study aimed to identify the driving variables that explain the species richness and the distribution of the bryophyte assemblages within the 7220 habitat. The environmental driving factors discussed within this study apply only to the 
TABLE 3: Results of the AIC stepwise model selection for species richness showing the best significant variables selected based on their weight using the complete dataset (columns on the left) or the data without 2 possible outliers (columns on the right).

\begin{tabular}{|c|c|c|c|c|c|c|}
\hline \multirow[b]{2}{*}{ Variable } & \multicolumn{2}{|c|}{ Weight of the variable } & \multicolumn{2}{|c|}{ Averaged coefficient } & \multicolumn{2}{|c|}{ Unconditional standard error } \\
\hline & Full model & $\begin{array}{l}\text { Model without } \\
\text { possible outliers }\end{array}$ & Full model & $\begin{array}{l}\text { Model without } \\
\text { possible outliers }\end{array}$ & Full model & $\begin{array}{l}\text { Model without } \\
\text { possible outliers }\end{array}$ \\
\hline Cover & 0.992 & 0.992 & -0.007 & -0.006 & 0.002 & 0.002 \\
\hline $\mathrm{PO}_{4}$ & 0.960 & 0.983 & -7.510 & -8.361 & 2.572 & 2.479 \\
\hline $\mathrm{NH}_{4}$ & 0.709 & 0.300 & -5.615 & -1.689 & 4.140 & 2.414 \\
\hline $\mathrm{Mg}$ & 0.650 & 0.548 & 0.009 & 0.007 & 0.006 & 0.005 \\
\hline pH_mean & 0.587 & 0.616 & -0.186 & -0.200 & 0.128 & 0.131 \\
\hline Zonecont & 0.309 & 0.300 & 0.065 & 0.058 & 0.086 & 0.080 \\
\hline $\mathrm{Ca}$ & 0.300 & 0.269 & 0.001 & 0.000 & 0.001 & 0.001 \\
\hline $\mathrm{NO}_{3}$ & 0.274 & 0.276 & 0.004 & 0.004 & 0.006 & 0.006 \\
\hline $\mathrm{NO}_{2}$ & 0.230 & 0.229 & -0.002 & -0.001 & 0.014 & 0.013 \\
\hline Slope moderate & 0.087 & 0.090 & 0.007 & 0.008 & 0.018 & 0.019 \\
\hline Slope steep & 0.087 & 0.09 & 0.005 & 0.008 & 0.021 & 0.023 \\
\hline
\end{tabular}

TABLE 4: Results of the AIC stepwise model selection for probability of presence of Palustriella commutata showing the best significant variables selected based on their weight using the complete dataset.

\begin{tabular}{lccc}
\hline Variable & Weight of the variable & Averaged coefficient & Unconditional standard error \\
\hline Moderate slope & 0.902 & 1.116 & 1.002 \\
Steep slope & 0.902 & 3.152 & 1.010 \\
Cover & 0.797 & -0.022 & 0.011 \\
pH_mean & 0.592 & -1.293 & 0.947 \\
$\mathrm{NH}_{4}$ & 0.387 & -13.210 & 14.475 \\
$\mathrm{NO}_{3}$ & 0.379 & 0.063 & 0.066 \\
$\mathrm{Ca}$ & 0.336 & -0.006 & 0.007 \\
$\mathrm{PO}_{4}$ & 0.283 & 1.874 & 3.610 \\
$\mathrm{NO}_{2}$ & 0.254 & -0.048 & 0.091 \\
$\mathrm{Mg}_{\text {Zonecont }}$ & 0.248 & -0.004 & 0.014 \\
\hline
\end{tabular}

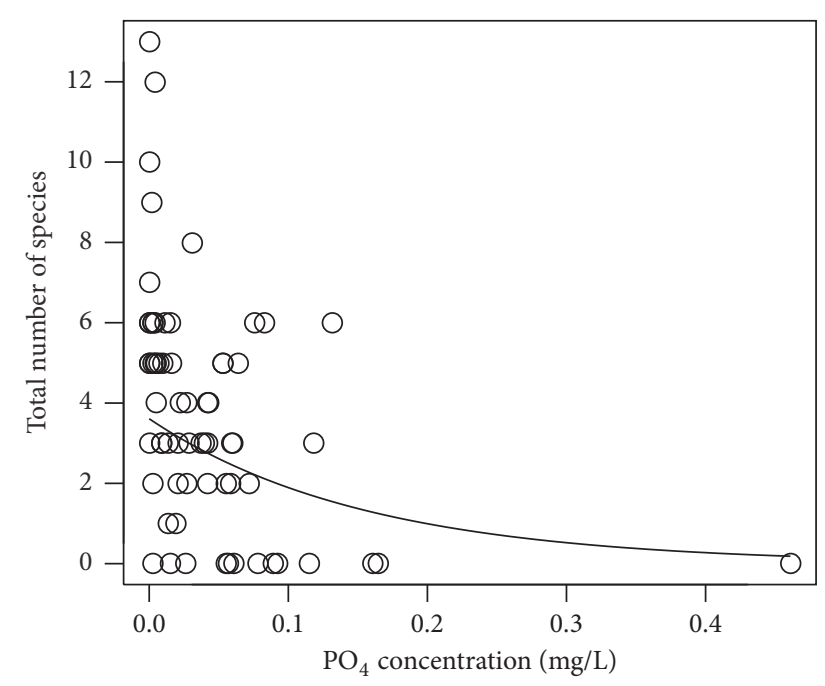

Figure 3: Prediction of species richness in relation to $\mathrm{PO}_{4}$ concentration based on the coefficients of the best models selected by AIC stepwise selection.

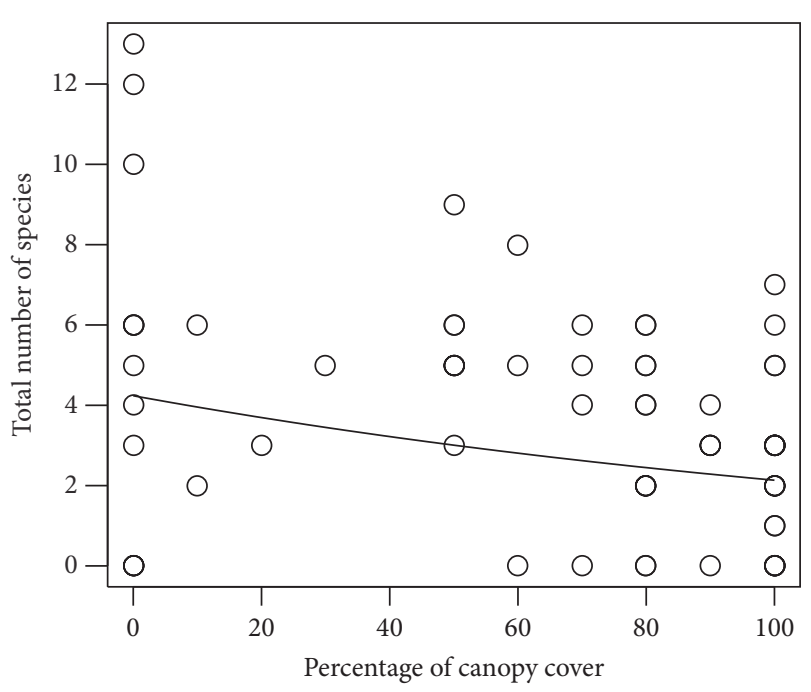

Figure 4: Prediction of species richness in relation to canopy cover based on the coefficients of the best models selected by AIC stepwise selection. 
TABLE 5: Results of the AIC stepwise model selection for probability of presence of Eucladium verticillatum showing the best significant variables selected based on their weight using the complete dataset.

\begin{tabular}{lccc}
\hline Variable & Weight of the variable & Averaged coefficient & Unconditional standard error \\
\hline Canopy cover & 0.931 & -0.031 & 0.013 \\
$\mathrm{NH}_{4}$ & 0.714 & -80.324 & 52.086 \\
$\mathrm{PO}_{4}$ & 0.523 & -17.784 & 15.728 \\
$\mathrm{NO}_{2}$ & 0.516 & 0.311 & 0.259 \\
$\mathrm{pH} \_$mean & 0.453 & -0.684 & 0.625 \\
Slope moderate & 0.445 & -0.256 & 0.675 \\
Slope steep & 0.445 & 0.862 & 0.772 \\
Zonecont & 0.383 & 6.353 & 878.235 \\
$\mathrm{NO}_{3}$ & 0.277 & -0.023 & 0.041 \\
$\mathrm{Mg}$ & 0.250 & 0.003 & 0.015 \\
$\mathrm{Ca}$ & 0.241 & 0.000 & 0.005 \\
\hline
\end{tabular}

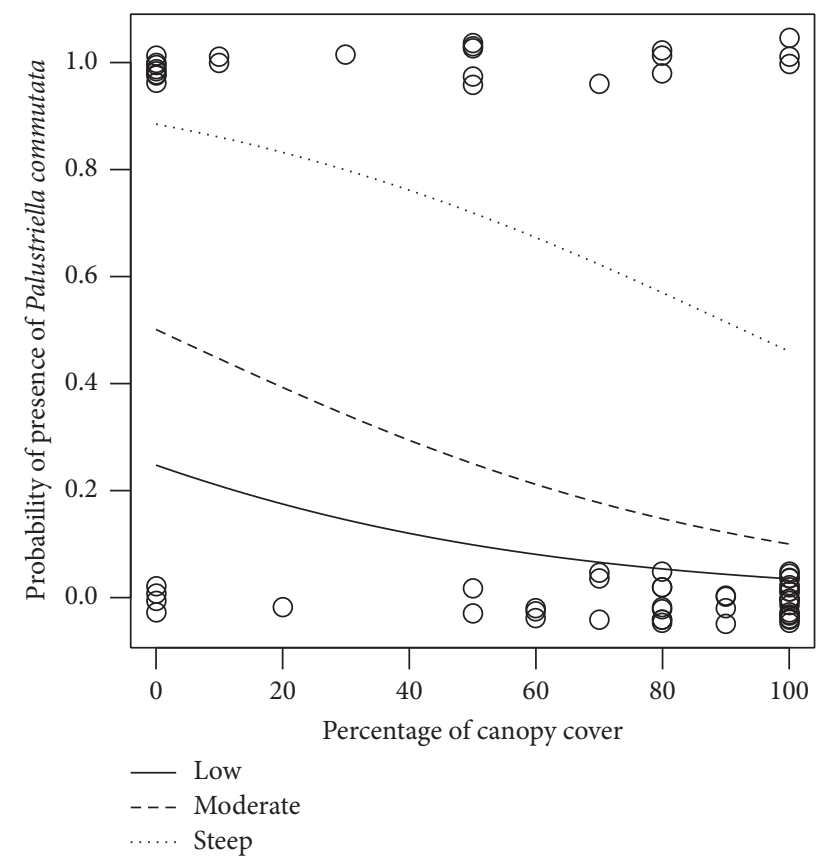

Figure 5: Prediction of presence of Palustriella commutata in relation to canopy cover based on the coefficients of the best models selected by AIC stepwise selection for different slopes: low slope (solid line), moderate slope (dashed line), and steep slope (dotted line).

7220 habitat of travertine forming springs and watercourses, and it would not be advisable to apply these findings outside of this habitat such as (less calcareous) types of water courses in Wallonia and Brussels-Capital Region. The springs and watercourses in this study are characterized by medium to high levels of $\mathrm{Ca}\left(60-300 \mathrm{mg} \cdot \mathrm{L}^{-1}\right)$ [40] and high $\mathrm{pH}$ values (7.5-8.5). The extreme values in our samples range from 76.5 to $251 \mathrm{mg} \cdot \mathrm{L}^{-1}$ for $\mathrm{Ca}$ (the 27.8 value seeming doubtful) and $\mathrm{pH}$ from 6.2 to 8.2. In comparison Brusa and Cerabolini [11] recorded $\mathrm{Ca}$ values between 33.2 and $60.2 \mathrm{mg} \cdot \mathrm{L}^{-1}$ and $\mathrm{pH}$ values between 7.5 and 8.4 .

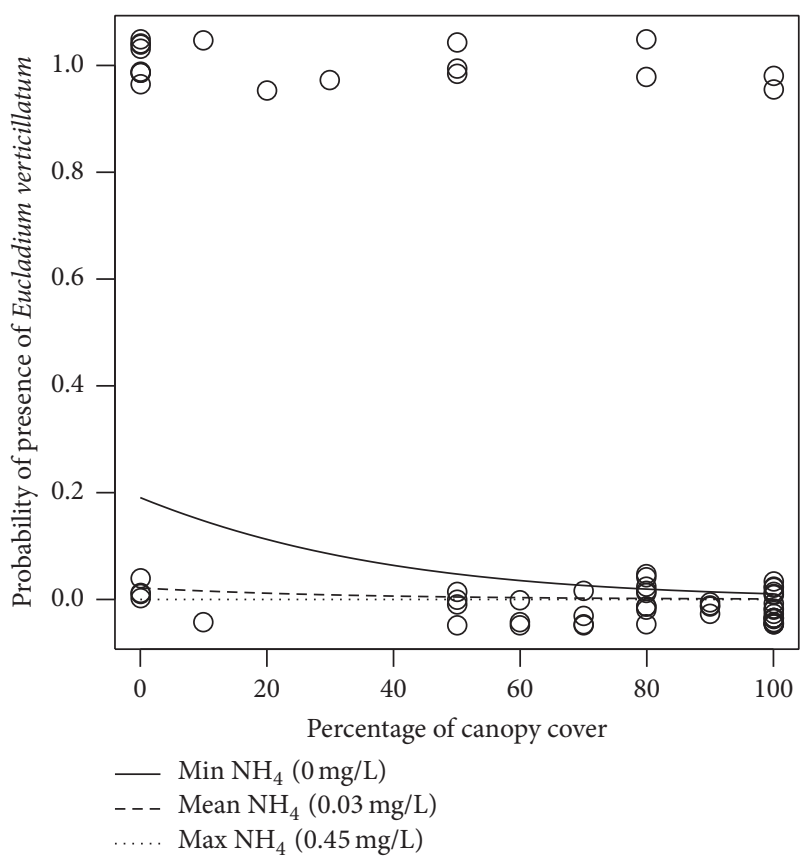

FIGURE 6: Prediction of presence of Eucladium verticillatum in relation to canopy cover based on the coefficients of the best models selected by AIC stepwise selection for different levels of $\mathrm{NH}_{4}$ : maximum concentration in the dataset (dotted line), mean concentration in the dataset (dashed line), and minimum concentration in the dataset (solid line).

4.1. Global Analysis. The results of the tb-RDA showed that only $36.5 \%$ of the total variance in the dataset can be explained by the environmental variables, considered within this study. This suggests that other variables not measured here could explain better the observed species assemblages. Following other authors [41, 42], we suggest that factors such as the substrate itself (sand, loam, and rock), the micro topography $[11,16,18,33,43]$, the water turbulence $[2,8$, $44]$, the distance from the spring $[8,13]$, the presence and characteristics of travertine-productive microorganisms like cyanobacteria $[8,16,45]$, and the local relative humidity could 
TABLE 6: Results of the AIC stepwise model selection for probability of presence of Cratoneuron filicinum showing the best significant variables selected based on their weight using the complete dataset.

\begin{tabular}{lccc}
\hline Variable & Weight of the variable & Averaged coefficient & Unconditional standard error \\
\hline $\mathrm{Mg}$ & 0.986 & 0.127 & 0.049 \\
$\mathrm{NH}_{4}$ & 0.734 & -21.408 & 17.105 \\
$\mathrm{PO}_{4}$ & 0.339 & -2.269 & 3.217 \\
$\mathrm{Ca}$ & 0.324 & -0.003 & 0.004 \\
$\mathrm{Cover}$ & 0.322 & -0.002 & 0.003 \\
$\mathrm{pH}$ mean & 0.261 & -0.110 & 0.227 \\
$\mathrm{Zonecont}$ & 0.257 & -0.019 & 0.231 \\
$\mathrm{NO}_{2}$ & 0.239 & 0.012 & 0.049 \\
$\mathrm{NO}_{3}$ & 0.238 & 0.005 & 0.022 \\
Slope moderate & 0.135 & 0.09 & 0.133 \\
Slope steep & 0.135 & -0.018 & 0.121 \\
\hline
\end{tabular}

TABLE 7: Results of the AIC stepwise model selection for probability of presence of Pellia endiviifolia showing the best significant variables selected based on their weight using the complete dataset.

\begin{tabular}{lccc}
\hline Variable & Weight of the variable & Averaged coefficient & Unconditional standard error \\
\hline $\mathrm{PO}_{4}$ & 0.922 & -28.250 & 13.310 \\
$\mathrm{NO}_{3}$ & 0.885 & 0.251 & 0.113 \\
$\mathrm{Ca}$ & 0.650 & -0.015 & 0.010 \\
$\mathrm{NO}_{2}$ & 0.448 & 0.168 & 0.157 \\
$\mathrm{NH}_{4}$ & 0.422 & -4.857 & 5.898 \\
Zonecont & 0.419 & -0.660 & 0.677 \\
Cover & 0.339 & -0.003 & 0.004 \\
$\mathrm{Mg}$ & 0.257 & 0.004 & 0.010 \\
$\mathrm{pH}{ }_{-}$mean & 0.240 & -0.095 & 0.273 \\
Slope moderate & 0.233 & 0.252 & 0.269 \\
Slope steep & 0.233 & 0.296 & 0.319 \\
\hline
\end{tabular}

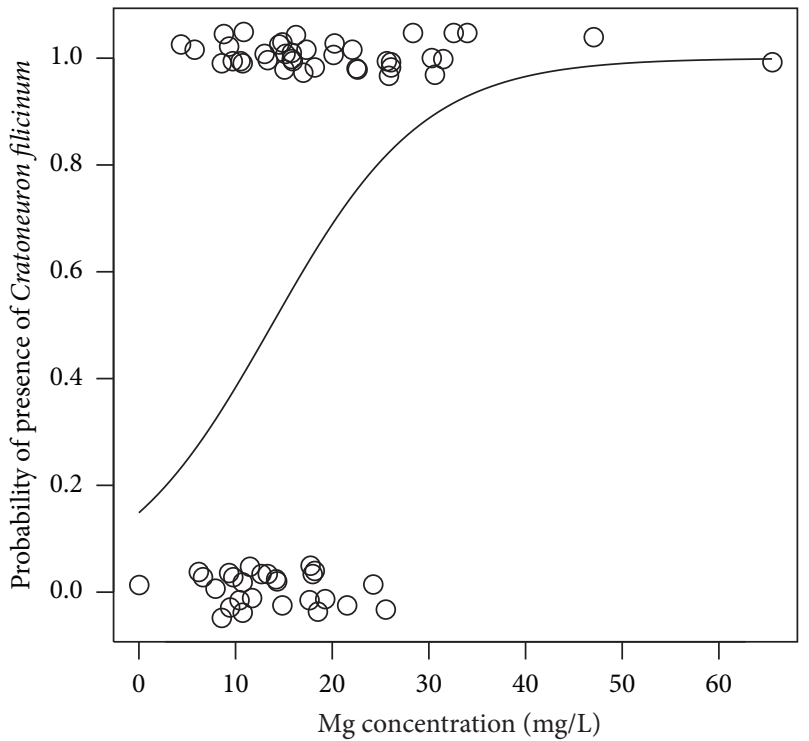

FIGURE 7: Prediction of presence of Cratoneuron filicinum in relation to $\mathrm{Mg}$ concentration based on the coefficients of the best models selected by AIC stepwise selection.

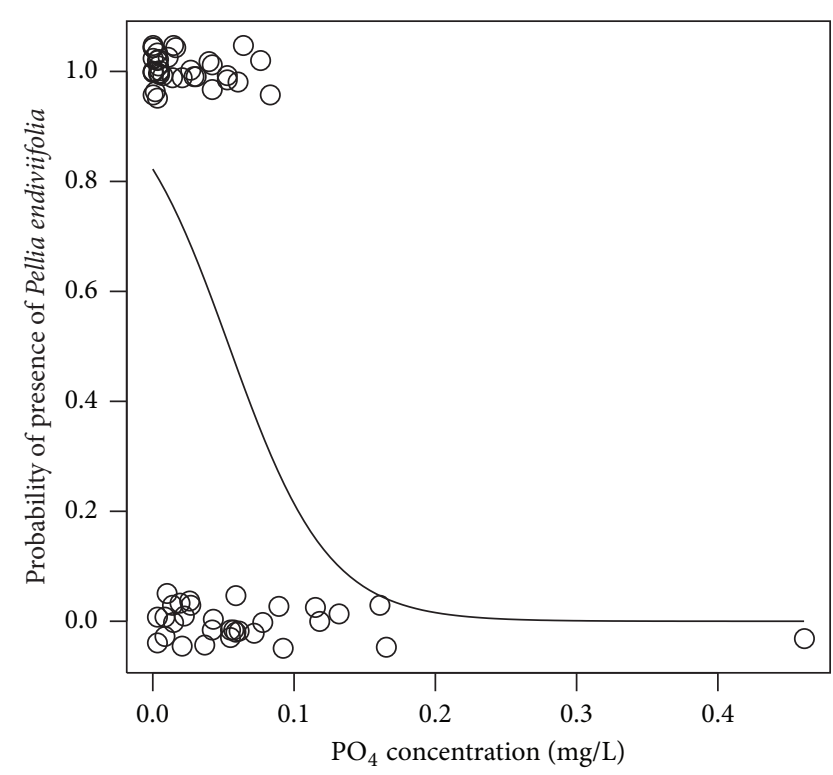

Figure 8: Prediction of presence of Pellia endiviifolia in relation to $\mathrm{PO}_{4}$ concentration based on the coefficients of the best models selected by AIC stepwise selection with the full dataset. 
TABLE 8: Results of the AIC stepwise model selection for probability of presence of Brachythecium rivulare showing the best significant variables selected based on their weight.

\begin{tabular}{lccc}
\hline Variable & Weight of the variable & Averaged coefficient & Unconditional standard error \\
\hline $\mathrm{Ca}$ & 0.894 & 0.023 & 0.010 \\
$\mathrm{PO}_{4}$ & 0.579 & -9.225 & 7.229 \\
Slope moderate & 0.468 & -0.193 & 0.369 \\
Slope steep & 0.468 & -0.897 & 0.650 \\
$\mathrm{pH} \_$mean & 0.354 & 0.354 & 0.414 \\
$\mathrm{NH}_{4}$ & 0.351 & -7.123 & 10.000 \\
Cover & 0.292 & 0.002 & 0.003 \\
Zonecont & 0.285 & -0.149 & 0.293 \\
$\mathrm{Mg}$ & 0.262 & 0.004 & 0.010 \\
$\mathrm{NO}_{3}$ & 0.251 & 0.009 & 0.025 \\
$\mathrm{NO}_{2}$ & 0.240 & 0.007 & 0.054 \\
\hline
\end{tabular}

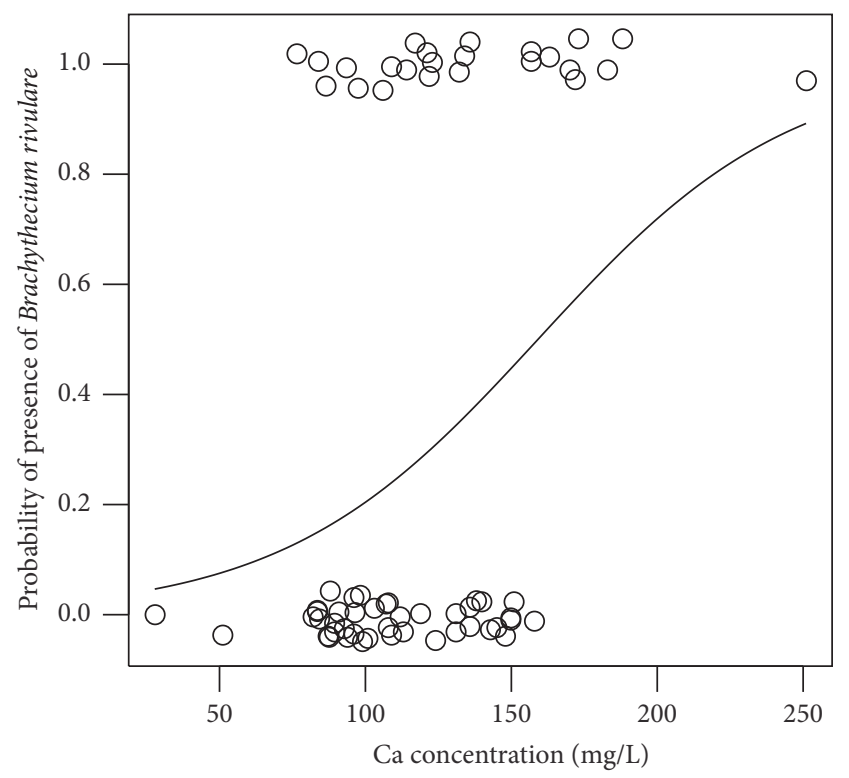

FIGURE 9: Prediction of presence of Brachythecium rivulare in relation to $\mathrm{Ca}$ concentration based on the coefficients of the best models selected by AIC stepwise selection.

play an important role in the species assemblages even if they would probably be difficult to quantify.

The results show that the most important variables explaining the rest of the variance are the slope, $\mathrm{NO}_{3}$, $\mathrm{NH}_{4}$, and $\mathrm{PO}_{4}$ concentrations (Figure 2). The slope has been identified by many authors as a key factor for the presence of the travertine communities [18] mainly because a steep slope generates more turbulence that enhances $\mathrm{CO}_{2}$ degassing and thus calcite precipitation that accounts for more than $80 \%$ of the precipitation in travertine $[13,45]$. The negative relationship between the $\mathrm{PO}_{4}$ concentration in the spring water and the presence of mosses specific to petrifying sources should be further explored but could possibly be explained by the fact that $\mathrm{PO}_{4}$ has an inhibitive role in the formation of calcite $[3,46,47]$. Pentecost [13] also highlights the negative role of phosphate pollution on the deposits formation and on the travertine communities. These results are partly confirmed by the forward selection that has similarly retained slope and canopy cover but also $\mathrm{Mg}$ and $\mathrm{Ca}$ (as well as $\mathrm{NH}_{4}$ when the 2 possible outliers are dropped). That means that the relief, the canopy cover, and the degree of eutrophication play an important role among the variables. It is not surprising that $\mathrm{NH}_{4}$ and $\mathrm{PO}_{4}$ variables act in the same way (Figure 2). More curiously though is the opposite relation between these two variables and the $\mathrm{NO}_{3}$ concentration though a similar observation has been made by Denys and Oosterlynck [48] in Flanders. The second axis showed that the canopy cover also plays an important role in the dispersion of the species assemblages. This result is expected since we know that the exposure and the degree of relative humidity play a key role in the ecology of most of bryophytes species [49].

The analysis also indicates that some species are more specifically linked to some variables considered in this study. Eucladium verticillatum and Palustriella commutata appear mostly in the same kind of locations characterized by a moderate or steep slope and with no or very low levels of eutrophication. This result is similar to analysis in Italy, using the same multivariate analysis [11]. Canopy cover is also negatively correlated with these sites indicating that these species occur more frequently at enlightened sites. Pellia endiviifolia shows a tendency to grow in $\mathrm{NO}_{3}$-rich sites, which is confirmed by other observation that the species can grow in oligotrophic and eutrophic waters [40]. Finally Brachythecium rivulare and Oxyrrhynchium hians are more likely to be found in more eutrophicated sites (determined by $\mathrm{PO}_{4}$ and $\mathrm{NH}_{4}$ values).

4.2. Species Richness. The Poisson GLM analysis and the AIC have retained two major significant variables concerning the species richness, that is, canopy cover and $\mathrm{PO}_{4}$ concentration. However other variables that have not been included in this analysis, such as soil type and water turbulence, should be considered in future studies. For example, Pentecost [13] has stated that two other variables, site size and heterogeneity, 
are also important factors affecting species richness. It can be seen in Figure 4 that all other registered variables being equal there could be a gain of only 2 or 3 species when clearing completely a theoretical site. This gain does not predict if the gained species would be characteristic species or other species.

The negative relation with $\mathrm{PO}_{4}$, and with $\mathrm{NH}_{4}$ when keeping the outliers in the dataset, indicates that the more oligotrophic the conditions the more rich the community. Other studies indicate that this kind of relationship is not always attributed to eutrophication, and human impacts are sometimes positively correlated to species richness [48]. These studies may address a wider range of conditions than in the present study and suggest that this relationship is scaledependent. The majority of the richest sites were characterized by $\mathrm{PO}_{4}$ concentration $<0.1 \mathrm{mg} \cdot \mathrm{L}^{-1}$ which is very close to the $0.05 \mathrm{mg} \cdot \mathrm{L}^{-1}$ threshold determined by Galoux et al. [41] for the reference conditions of Walloon watercourses. Brusa and Cerabolini [11] in Italy using multivariate analysis found that the 3 major factors explaining their species assemblages were the permanency/nonpermanency of the water flow, the slope, and the canopy cover. In this study the slope is not retained in the species richness analysis; however, it is an important variable for Palustriella commutata.

\subsection{Characteristic and Companion Species}

4.3.1. Palustriella commutata. Our analysis shows that slope and to a lesser extend canopy cover are important variables explaining the presence of Palustriella commutata in the surveyed sites. The absence of canopy combined with a steep slope increases the probability of presence of Palustriella commutata (Figure 5). The slope has been detected as the only significant variable by Brusa and Cerabolini [11]. The fact that slope seems to play an important role in the probability of presence of the species seems contradictory with the wellknown occurrence of the species in calcareous meadows in Belgium [16, 28]. It is possible that the properties of the water including highly mineralized or calcareous waters and permanently wet surfaces could be even more important than slope $[11,19,28,50]$. It has been mentioned by many authors $[13,43,51,52]$ that there are two subspecies or species [14] Palustriella commutata and P. falcata whose ecological preferences are slightly different. According to these authors $P$. commutata occurs relatively more often on boggy sites and around small springs and seepages with a higher $\mathrm{pH}$ and higher Ca concentrations, and it tolerates higher rates of nitrates and grows almost exclusively on limestone. $P$. falcata seems more restricted to open habitat of turbulent water at higher altitude and in less bases-rich waters. Concerning the canopy cover other authors $[1,13,18,50]$ mention the fact that this factor must play a role even if the species tolerates much shade. The species seems also to tolerate a certain amount of eutrophication $[18,34,50]$ even if it grows mostly in oligotrophic circumstances.

4.3.2. Eucladium verticillatum. Although canopy cover and $\mathrm{NH}_{4}$ are both negatively linked with the probability of presence of the species these variables seem not to play a major role. It is probable that other variables could also influence species richness including less permanently wet substrate by capillarity or because of being splashed. Indeed we found the species abundant around a spring on a steep sandy substrate in the Rouge-Cloître in the Brussels-Capital Region that is not splashed at all but is permanently wet due to capillarity and high relative humidity. The relative weak negative relationship with canopy cover is mentioned by some authors $[2,24,50]$ that found the species in much shaded habitats.

4.3.3. Cratoneuron filicinum. This species is not recognized in Wallonia as a characteristic species of the 7220 habitat as it is widely distributed [19], occupying calcareous meadows, calcareous springs, and wet rocks, as well as forest tracks where dolomite gravels have been added to harden the soil. In the Walloon watercourses Cratoneuron filicinum has been identified as one of the few indicative species of more or less calcareous streams [41]. In our sites the species has a relatively wide ecological amplitude as regards canopy cover and light to moderate eutrophication. The tolerance to a certain level of eutrophication is also mentioned by Bailly et al. [50] and by Sossey-Alaoui and Rosillon [40]. Mg proves to be a keyelement in our sites and this observation should be related to the fact that the species is especially common on dolomite substrates, such as forests tracks that are rich in $\mathrm{Mg}$, as well as on marl substrates in Lorraine [19].

4.3.4. Pellia endiviifolia. This is a widespread species in Wallonia and Brussels $[19,53]$ commonly associated with neutral to basic waters. It is also known to tolerate shade as well as moderately eutrophic waters [50]. It is therefore not surprising that none of these variables show clear relationships with the probability of presence in our sites. The apparent contradictory relationships with $\mathrm{PO}_{4}$ and $\mathrm{NO}_{3}$ are hard to clarify. Sossey-Alaoui and Rosillon [40] indicate that the species can be an indicator species both in oligotrophic streams and in nitrates-rich streams, providing that the waters are mineral-rich (high conductivity/high $\mathrm{Ca}$ concentration).

4.3.5. Brachythecium rivulare. Together with Pellia endiviifolia this species is relatively widespread in Wallonia and Brussels-Capital Region $[19,53]$. It occurs along water courses and in marshes, though it is less linked to calcareous waters. In Wallonia it has been demonstrated that it has very wide ecological amplitude that is common in every natural region independent of the substrate [41]. It has also wide ecological amplitude occurring in a range of trophic levels and tolerating shade but preferring open sites [50]. This high ecological amplitude mirrors in the quasi-absence of significant variables explaining the presence of the species in our dataset.

4.4. Management Measures. One of the main objectives of this study was to define management objectives that could be implemented to maintain or improve the conservation 
status of the habitat 7220 . As only relatively small proportion of the observed variability can be explained by the surveyed variables; the inclusion of further variables is recommended for future studies. Additionally among the surveyed variables some cannot be managed at all like the slope and $\mathrm{Mg}$ concentrations. Nevertheless, our results provide information on key variables that should be considered when managing these sites. The management measures may be different depending on their intention and may vary if the aim is to enhance biodiversity or favouring particular species. Generally speaking, we have seen that one of the most prominent results is that the species assemblage characteristic of the 7220 habitat (Palustriella commutata and Eucladium verticillatum) favours very low $\mathrm{PO}_{4}$ concentration $\left(\mathrm{PO}_{4}<0.2 \mathrm{mg} \cdot \mathrm{L}^{-1}\right)$ and low canopy cover. This is also the case but to a lesser degree with $\mathrm{NH}_{4}$. Graham and Farr [34] have stated that these two species are also mostly present when $\mathrm{PO}_{4}$ concentration is less than $0.05 \mathrm{mg} \cdot \mathrm{L}^{-1}$. Brachythecium rivulare, Oxyrrhynchium hians, and even Pellia endiviifolia can occur in eutrophic conditions; however, in these conditions there is a lower probability of presence of the two characteristic species.

The more open the site the more diverse the moss assemblages will be even if the expected number of additional species is only 2 or 3 (Figure 4); however, the favoured species would not automatically be characteristic species of the 7220 habitat. If canopy cover plays a role in favouring species richness, it would be advisable not to cut down all existing trees and bushes but to undertake thinning to avoid possible radical negative changes in relative humidity and temperature on the bryophyte communities.

We recommend that regular monitoring of the water chemistry is the best way to detect abnormal changes especially eutrophication $\left(\mathrm{PO}_{4}, \mathrm{NH}_{4}, \mathrm{NO}_{3}\right)$. Monitoring regimes are already in place for most of the Walloon and Brussels sites but should be extended to all 7220 known sites.

4.5. Suggestions for Future Studies. To try to intercept other significant factors in the distribution and the presence/absence of the most characteristic species of the 7220 habitat, further studies should seek to take into account the following variables: type of substrate (sandy, calcareous, silty, etc.), the micro topography, the water turbulence, the distance from the spring, the relative humidity, and the presence of algae/cyanobacteria.

\section{Conclusions}

In this study, we highlighted the variables explaining the species richness and the distribution of moss assemblages of the 7220 habitat in the southern part of Belgium. The driving factors highlighted in this study can only be applied to the 7220 habitat and would probably not be valuable for studies at sites dominated by less calcareous waters in Wallonia and Brussels-Capital Region. Our study recommends that monitoring of water chemistry (eutrophication) should be applied to all 7220 habitats, and this information should be used to support practical management actions to maintain or achieve a good status of conservation.

\section{Competing Interests}

The authors declare that they have no competing interests.

\section{Acknowledgments}

The authors would like to thank their colleagues Fabrice Etienne and Etienne Peiffer who collected the water samples and recoded the site variables. Other colleagues helped them when measuring the parameter, Daniel Galoux and Jonathan Devriese. Christine Keulen provided them with useful information about the thresholds of the different water courses in Wallonia. Mathias Engelbeen and Wim Van Den Eynden gave them access to the sites of the Brussels-Capital Region. They are also very grateful to David Zeleny who kindly accepted to check their multivariate analysis. They thank Gareth Farr (British Geological Survey) for undertaking a review of the English manuscript. Finally, they would like to thank Pierre Gerard who allowed them to carry out this study.

\section{References}

[1] J.-J. Symoens, P. Duvigneaud, and C. Vanden Berghen, "Aperçu sur la végétation des tufs calcaires de la Belgique," Bulletin de la Société Royale de Botanique de Belgique Tome, vol. 83, pp. 329352, 1951.

[2] J.-M. Couderc, "Les groupements muscinaux des tufs de Touraine," Documents Phytosociologiques N.S., vol. 1, pp. 37-50, 1977.

[3] A. Pentecost, "The tufa deposits of the Malham district, north Yorkshire," Field Studies, vol. 5, no. 3, pp. 365-387, 1981.

[4] P. De Zuttere, Aperçu bryosociologique des tufs calcaires actifs de moyenne et haute Belgique. Colloques phytosociologiques, $\mathrm{X}$ "Les végétations aquatiques et amphibies" (Lille, 1981), pp. 279293, https://inpn.mnhn.fr/docs/cahab/habitats-declines/7220 .pdf.

[5] H. A. Viles and A. S. Goudie, "Tufas, travertines and allied carbonate deposits," Progress in Physical Geography, vol. 14, no. 1, pp. 19-41, 1990.

[6] T. D. Ford and H. M. Pedley, "A review of tufa and travertine deposits of the world," Earth-Science Reviews, vol. 41, no. 3-4, pp. 117-175, 1996.

[7] A. Janssen and R. Swennen, "Petrography and geochemistry of the travertine deposit at Treignes (S. Belgium)," Bulletin de la Société Belge de Géologie, vol. 106, pp. 97-115, 1997.

[8] M. Merz-Preiß and R. Riding, "Cyanobacterial tufa calcification in two freshwater streams: ambient environment, chemical thresholds and biological processes," Sedimentary Geology, vol. 126, no. 1-4, pp. 103-124, 1999.

[9] R. Boch, C. Spötl, J. M. Reitner, and J. Kramers, "A lateglacial travertine deposit in Eastern Tyrol (Austria)," Austrian Journal of Earth Sciences, vol. 98, pp. 78-91, 2005.

[10] B. Franco, G. Houbrechts, J. Van Campehout, E. Hallot, and F. Petit, "Etude géomorphologique des barrages de travertin du Hoyoux," Bulletin de la Société Géographique de Liège, vol. 50, pp. $45-56,2008$.

[11] G. Brusa and B. E. L. Cerabolini, "Ecological factors affecting plant species and travertine deposition in petrifying springs from an Italian 'Natura 2000' site," Botanica Helvetica, vol. 119, no. 2, pp. 113-123, 2009. 
[12] European Commission, "Interpretation Manual of European Union Habitats-Eur28. European Commission, DG Environment, Nature \& Biodiversity," 2013, http://ec.europa.eu/environment/nature/legislation/habitatsdirective/docs/Int_Manual_ EU28.pdf.

[13] A. Pentecost, Travertine, Springer, Berlin, Germany, 2005.

[14] M. O. Hill, N. Bell, M. A. Bruggeman-Nannenga et al., "An annotated checklist of the mosses of Europe and Macaronesia," Journal of Bryology, vol. 28, no. 3, pp. 198-267, 2006.

[15] L.-M. Delescaille, L. Wibail, H. Claessens et al., Eds., Les Cahiers d'Habitats d'Intérêt Communautaire de Wallonie, Publication du Département de l'Étude du Milieu Naturel et Agricole (SPW-DGARNE), Faune-Flore-Habitats, Gembloux, Belgium, 2017.

[16] P. Oosterlynck and W. Van Landuyt, "Kalktufbronnen in vlaanderen: mythe of werkelijkheid?" Muscillanea, vol. 32, pp. 36-52, 2012.

[17] JNCC, Joint Nature Conservation Committee, Habitat account -7220 Petrifying springs with tufa formation (Cratoneurion), 2015, http://jncc.defra.gov.uk/ProtectedSites/ SACselection/habitat.asp?FeatureIntCode $=\mathrm{H} 7220$.

[18] K. van Dort, L. van Oirschot-Beerens, and H. Weinreich, "Bryophyte vegetation in petrifying springs with tufa in Limburg (The Netherlands)," Natuurhistorisch Maandblad, pp. 165$173,2012$.

[19] A. Sotiaux and A. Vanderpoorten, Atlas des Bryophytes (Mousses, Hépatiques, Anthocérotes) de Wallonie (19802014), Série "Faune-Flore-Habitats" no. 9, Publication du Département de l'Etude du Milieu Naturel et Agricole (SPWDGARNE), Gembloux, Belgium, 2015.

[20] J.-J. Symoens, "Note sur les formations de tuf calcaire observées dans le Bois d'Hautmont (Wauthier-Braine)," Bulletin de la Société Royale de Botanique de Belgique, vol. 82, no. 1, pp. 8195, 1949.

[21] J. De Sloover and M. Goossens, "Les associations du Cratoneurion d'un travertin de Lorraine belge," Bulletin de la Société Royale Botanique de Belgique, vol. 117, pp. 37-50, 1984.

[22] J. Duvigneaud and J. Saintenoy-Simon, "Les tufs calcaires des Fonds de Leffe à Dinant," Les Naturalistes Belges, vol. 72, no. 4, pp. 113-120, 1991.

[23] J. Duvigneaud and J. Saintenoy-Simon, "Deux tufs calcaires sur Famennien à Hastière et à Blaimont (province de Namur)," Les Naturaliste Belges, vol. 73, no. 4, pp. 199-204, 1992.

[24] M.-T. Romain, “Cron de neuville," Les Barbouillons, vol. 203, pp. 114-116, 2001.

[25] H. Zechmeister and L. Mucina, "Vegetation of European springs: high-rank syntaxa of the Montio-Cardaminetea," Journal of Vegetation Science, vol. 5, no. 3, pp. 385-402, 1994.

[26] J. Bardat and J.-C. Hauguel, "Synopsis bryosociologique pour la France," Cryptogamie, Bryologie, vol. 23, no. 4, pp. 279-343, 2002.

[27] B. Van Gennip, J. A. M. Janssen, and E. J. Weeda, "De kalktufbron, kleinood met een grote status," Stratiotes, vol. 35, pp. 22-37, 2007.

[28] G. Noulard-Weyembergh, "Une station de Carex lepidocarpa et de Palustriella commutata dans la vallée de l'Argentine (Overijse, district brabançon)," Adoxa, vol. 75, pp. 7-12, 2013.

[29] M. Tomaselli, D. Spitale, and A. Petraglia, "Phytosociological and ecological study of springs in Trentino (south-eastern Alps, Italy)," Journal of Limnology, vol. 70, supplement 1, pp. 25-53, 2011.
[30] G. Bailly, Identification des Habitats Aquatiques et des Formations Tufeuses de la Haute Seille, Conservatoire Botanique de Franche-Comté, Besançon, France, 2005.

[31] M. L. H. Boyer and B. D. Wheeler, "Vegetation patterns in spring-fed calcareous fens: calcite precipitation and constraints on fertility," Journal of Ecology, vol. 77, no. 2, pp. 597-609, 1989.

[32] A. Pentecost, "A note on the stable carbon isotope composition of bryophytes in calcareous aquatic habits and its relationship to carbon dioxide assimilation," Journal of Bryology, vol. 22, no. 1, pp. 13-15, 2000.

[33] A. Pentecost and Z. Zhaohui, "Bryophytes from some travertine-depositing sites in France and the U.K.: relationships with climate and water chemistry," Journal of Bryology, vol. 24, no. 3, pp. 233-241, 2002.

[34] J. Graham and G. Farr, "Petrifying springs in Wales. Report of the first systematic survey of 'tufa' springs in Wales," Field Bryology, vol. 112, pp. 19-29, 2014.

[35] P. Oosterlynck and E. De Bie, "Kalktufbronnen in Vlaanderen. Bryologische en abiotische karakterisering van een Natura 2000 habitattype op de rand van zijn verspreiding," Rapporten van het Instituut voor Natuur- en Bosonderzoek, Brussels, Belgium.

[36] R Core Team, R: A Language and Environment for Statistical Computing, R Foundation for Statistical Computing, Vienna, Austria, 2014, https://www.R-project.org/.

[37] P. Legendre and E. D. Gallagher, "Ecologically meaningful transformations for ordination of species data," Oecologia, vol. 129, no. 2, pp. 271-280, 2001.

[38] J. Oksanen, F. Guillaume Blanchet, R. Kindt et al., Vegan: Community Ecology Package. R package version 2.3-0, 2015, http://CRAN.R-project.org/package=vegan.

[39] K. P. Burnham and D. R. Anderson, Model Selection and Multimodel Inference: A Practical Information-Theoretic Approach, Springer, New York, NY, USA, 2nd edition, 2002.

[40] K. Sossey-Alaoui and F. Rosillon, "Macrophytic distribution and trophic state of some natural and impacted watercoursesBelgium Wallonia," International Journal of Water Sciences, vol. 2, pp. 1-11, 2013.

[41] D. Galoux, F. Chérot, F. Rosillon, and K. Sossey-Alaoui, "Contribution to the macrophytic typology of belgian reference watercourses," Advances in Botany, vol. 2015, Article ID 651369, 13 pages, 2015.

[42] A.-M. Geurts, "Formation des travertins de fond de vallée sous climat tempéré océanique," Comptes-Rendus de l'Académie des Sciences de Paris D, vol. 282, pp. 275-276, 1976.

[43] G. Farr, J. Graham, and C. Stratford, "Survey characterisation and condition assessment of Palustriella dominated springs H7220 Petrifying springs with tufa formation (Cratoneurion)," Centre for Ecology and Hydrology and the British Geological Survey (NERC) Internal Report WL/NEC02832/13_14/T6, 2014.

[44] A. Pentecost, "Moss growth and travertine deposition: the significance of photosynthesis, evaporation and degassing of carbon dioxide," Journal of Bryology, vol. 19, no. 2, pp. 229-234, 1996.

[45] G. Arp, A. Bissett, N. Brinkmann et al., "Tufa-forming biofilms of German karstwater streams: microorganisms, exopolymers, hydrochemistry and calcification," Geological Society, London, Special Publications, vol. 336, pp. 83-118, 2010.

[46] P. M. Dove and M. F. Hochella Jr., "Calcite precipitation mechanisms and inhibition by orthophosphate: in situ observations by Scanning Force Microscopy," Geochimica et Cosmochimica Acta, vol. 57, no. 3, pp. 705-714, 1993. 
[47] L. J. Plant and W. A. House, "Precipitation of calcite in the presence of inorganic phosphate," Colloids and Surfaces A: Physicochemical and Engineering Aspects, vol. 203, no. 1-3, pp. 143-153, 2002.

[48] L. Denys and P. Oosterlynck, "Diatom assemblages of nonliving substrates in petrifying Cratoneurion springs from lower Belgium," Fottea, vol. 15, no. 2, pp. 123-138, 2015.

[49] A. Vandepoorten and B. Goffinet, Introduction to Bryophytes, Cambridge University Press, New York, NY, USA, 2009.

[50] G. Bailly, J.-C. Vadam, and J.-P. Vergon, Guide Pratique d'Identification des Bryophytes Aquatiques, DIREN FrancheComté, 2004.

[51] L. Hedenäs and A. Kooijman, "Habitat differentiation within Palustriella," Lindbergia, vol. 29, no. 1, pp. 40-50, 2004.

[52] H. Stieperaere, "Palustriella commutata en P. falcata in Vlaanderen," Muscillanea, vol. 26, pp. 32-36, 2007.

[53] A. Vanderpoorten, A Bryological Survey of the Brussels Capital Region (Belgium), vol. 14, Scripta Botanica Belgica, 1997. 


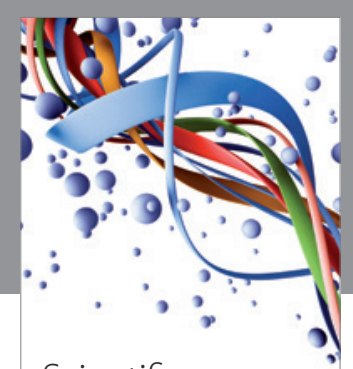

Scientifica
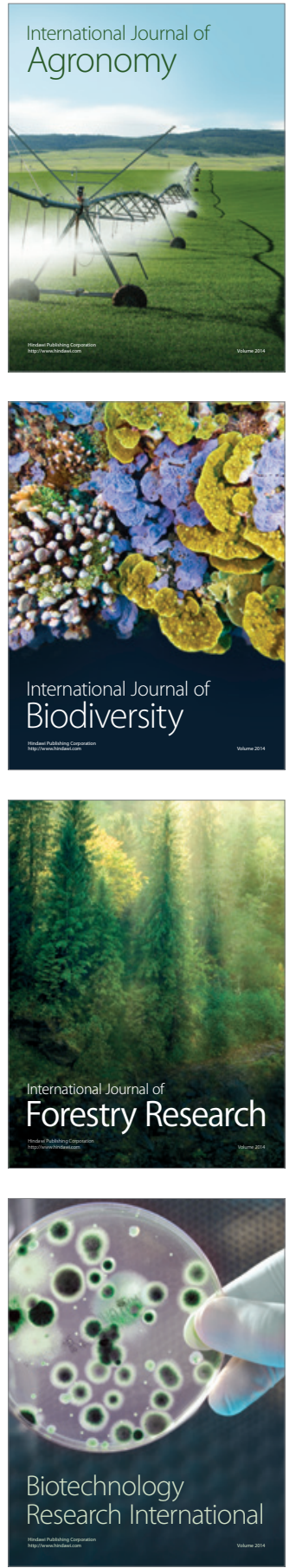
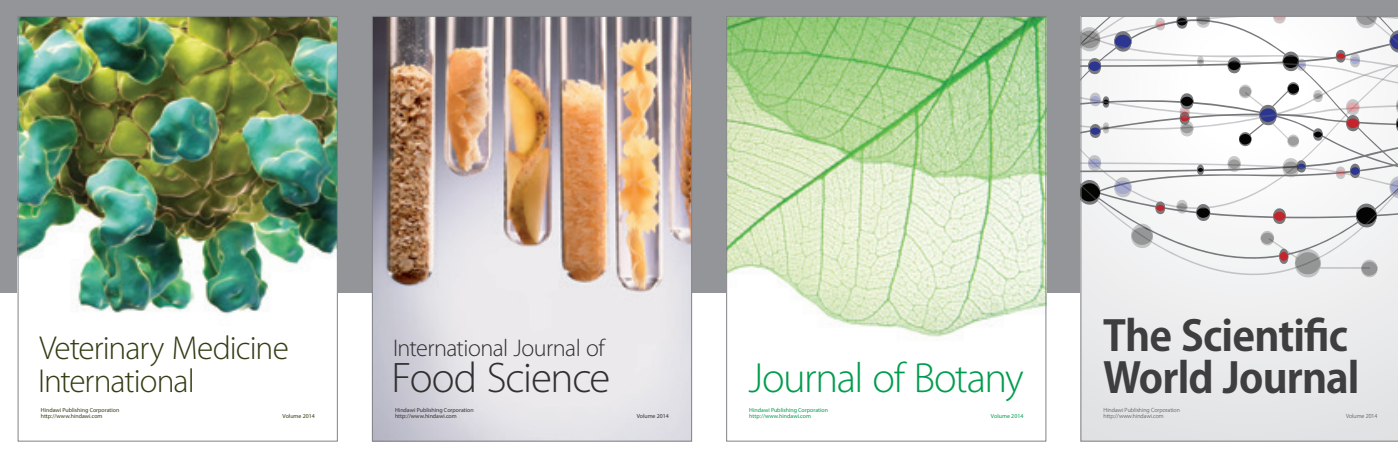

The Scientific

\section{World Journal}

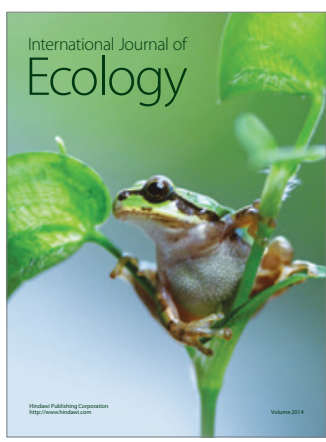

\section{Hindawi}

Submit your manuscripts at

http://www.hindawi.com
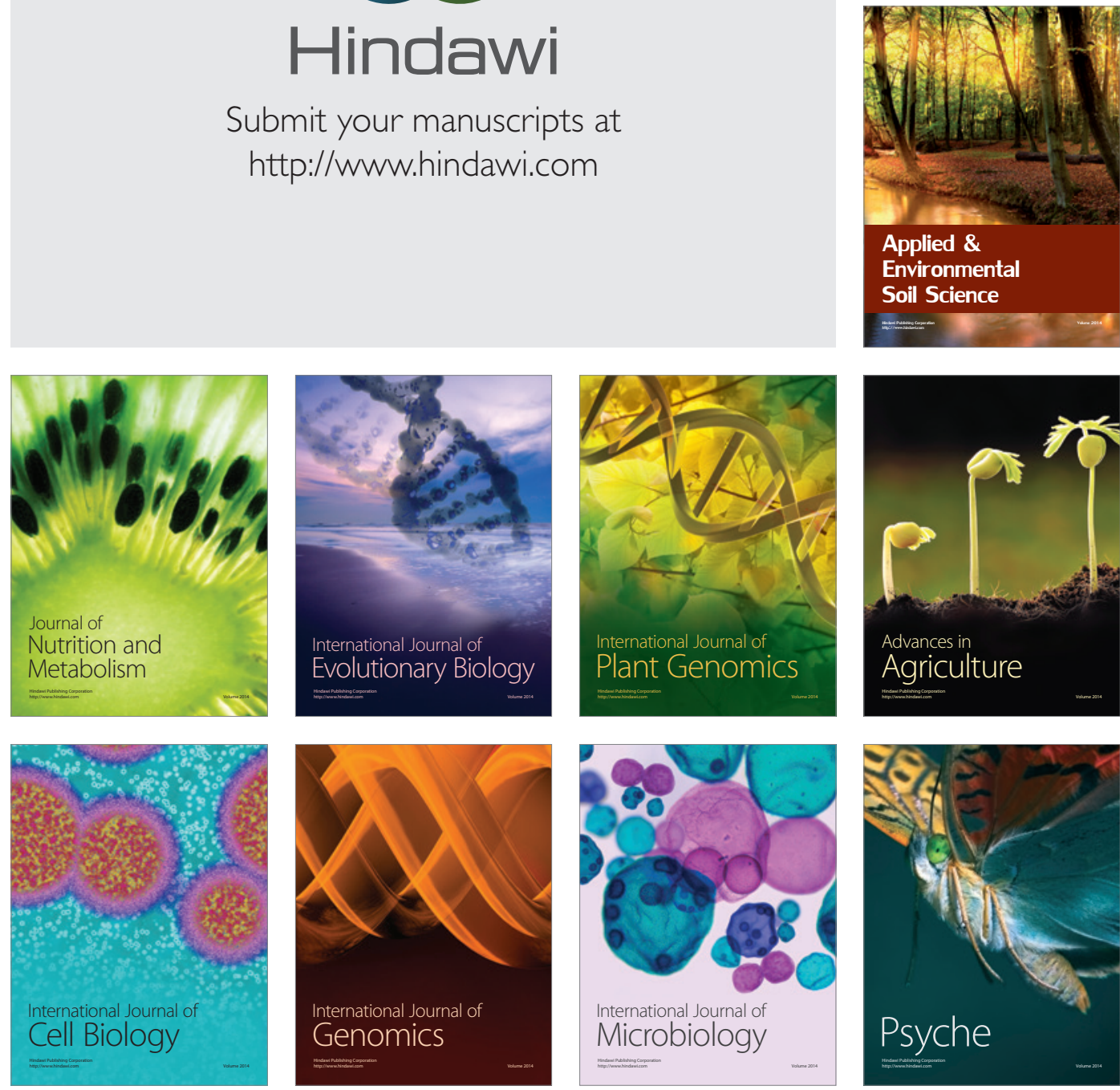
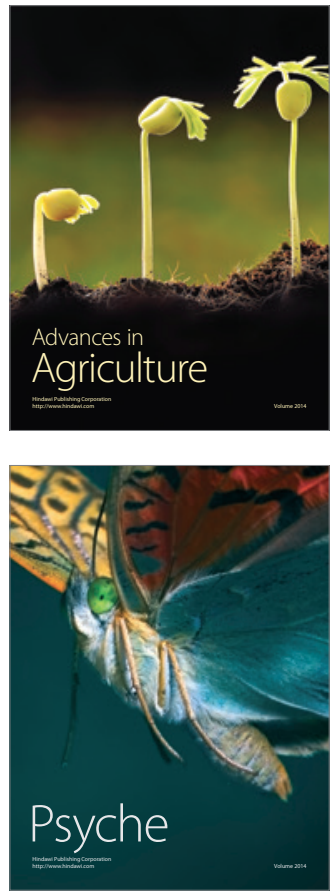